\title{
Indirect contributions of forests to dietary diversity in Southern Ethiopia
}

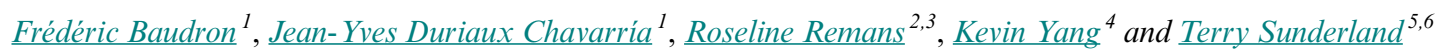

\begin{abstract}
We assess whether forests contribute indirectly to the dietary diversity of rural households by supporting diverse agricultural production systems. We applied our study in a landscape mosaic in Southern Ethiopia that was divided into three zones of increasing distance to Munesa Forest- "near," "intermediate," and "distant." A variety of research tools and methods, including remote sensing, participatory methods, farm survey, and yield assessment, were employed. Diets of households were more diverse in the near zone than in the other two zones $(6.58 \pm 1.21,5.38 \pm 1.02$, and $4.41 \pm 0.77$ food groups consumed daily in the near, intermediate, and distant zones, respectively). This difference was not explained by food items collected from Munesa Forest but by biomass flows from the forest to farmlands. Munesa Forest contributed an average of $6.13 \pm 2.90$ tons of biomass per farm and per year to the farms in the near zone, in the form of feed and fuelwood. Feed from the forest allowed for larger livestock herds in the near zone compared with the other two zones, and fuelwood from the forest reduced the need to use cattle dung as fuel in the near zone compared with the two other zones. These two biomass flows contributed to the availability of more manure to farmers closer to the forest $\left(908 \pm 853 \mathrm{~kg} \mathrm{farm}^{-1}, 771 \pm 717\right.$ $\mathrm{kg} \mathrm{farm}^{-1}$, and $261 \pm 487 \mathrm{~kg} \mathrm{farm}^{-1}$ in the near, intermediate, and distant zones, respectively). In turn, increased manure enabled a larger percentage of farms to cultivate a diversified homegarden $(87,64$, and $39 \%$ of farms in the near, intermediate, and distant zones, respectively). Homegardens and livestock products provided the greater contribution to household dietary diversity closer to the forest.
\end{abstract}

Key Words: fuelwood; homegarden; landscape mosaic; livestock; nontimber forest products; nutrition; nutrition-sensitive agriculture

\section{INTRODUCTION}

Since the Green Revolution, the global number of undernourished people-i.e., those not consuming sufficient calories - has declined (Gómez et al. 2013). Although there are still an estimated 800 million people suffering from caloric undernutrition, many more people today suffer from "hidden hunger" or a lack of vitamins and minerals (IFPRI 2014). As such, an estimated two billion people are currently affected by micronutrient deficiencies (Muthayya et al. 2013, IFPRI 2014). Micronutrient adequacy is strongly associated with dietary diversity (Foote et al. 2004, Steyn et al. 2006). The contribution of agriculture to the dietary diversity of rural people, through food production pathways (Jones et al. 2014) and income pathways (Sibhatu et al. 2015), is relatively well understood. Several recent case studies from around the world have also found a positive association between proximity to forests and dietary diversity (Dounias and Froment 2006, Powell et al. 2011, Johnson et al. 2013, Ickowitz et al. 2014). For example, using data from 21 African countries on children's diets (from USAID's Demographic Health Surveys) and tree cover (from MODIS data), Ickowitz et al. (2014) found that children in Africa who lived in areas with more tree cover had more diverse and nutritious diets.

With forests disappearing at an alarming rate in the tropics (Gibbs et al. 2010), better understanding of their overall contribution to the dietary diversity of rural people living in their vicinity is increasingly important. However, research on the relationship between forest cover and dietary diversity remains somewhat limited. Forests contribute directly to diets of people through the provisioning of a diversity of wild forest-sourced foods, such as mushrooms, berries, bushmeat, and fruits-Pathway 1 (Hladik et al. 1990, Fa et al. 2003, Vinceti et al. 2008, Nasi et al. 2011, Termote et al. 2011). In addition, access to fuelwood can facilitate the cooking process of a range of food items, such as legumes, which, on average, require a long cooking time-Pathway 2 (Remans et al. 2011). The collection and sale of nontimber forest products (i.e., any wild biological resource - animal or plant - harvested from forested lands by rural households for domestic consumption or small-scale trade, with no, or limited, capital investment) (Shackleton et al. 2007) also contribute to people's incomePathway 3 (Williams 1998, Beck and Nesmith 2001, Kaschula et al. 2005, Pfund et al. 2011) — which, in turn, may contribute to better economic access to a diversity of food items that are available in markets. Access to nontimber forest products is critical for poverty alleviation and mitigation because it allows the poorest and most vulnerable rural households to use these free resources to meet their daily needs for energy, shelter, food, and medicine, and to save their scarce cash resources to meet other needs or accumulate assets for more secure livelihoods (Shackleton and Shackleton 2004, Shackleton et al. 2007). Nontimber forest products also provide rural households with a safety net - Pathway 4 -in times of crises; e.g., drought, illness, or other external shocks (Shackleton and Shackleton 2004, Shackleton et al. 2007, Arnold et al. 2011). Forest may be the most profitable land use for degraded land, complementing income from crop and livestock production on more favorable parts of the landscape (Jagger and Pender 2003).

Forests may also contribute to dietary diversity of rural people through a fifth pathway, by supporting diverse agricultural production. In African smallholder farming systems characterized by low fertilizer use, trees are important to maintain soil fertility, which supports the productivity of food crops (Sanchez et al. 1997, Foli et al. 2014). Biodiversity-rich forests also supply numerous ecosystem services, including pollination and pest control (Pimentel et al. 1997, Reed et al. 2017). Using the case study of a landscape of Southern Ethiopia that is characterized by a gradient of increasing distance from a natural forest (Munesa Forest) and

\footnotetext{
${ }^{1}$ International Maize and Wheat Improvement Centre (CIMMYT), ${ }^{2}$ Bioversity International, ${ }^{3}$ Faculty of Bioscience Engineering, Ghent University, ${ }^{4}$ Department of Forest and Conservation Sciences, University of British Columbia, ${ }^{5}$ Center for International Forestry Research (CIFOR), ${ }^{6}$ James Cook University
} 
Fig. 1. Map of the study area.

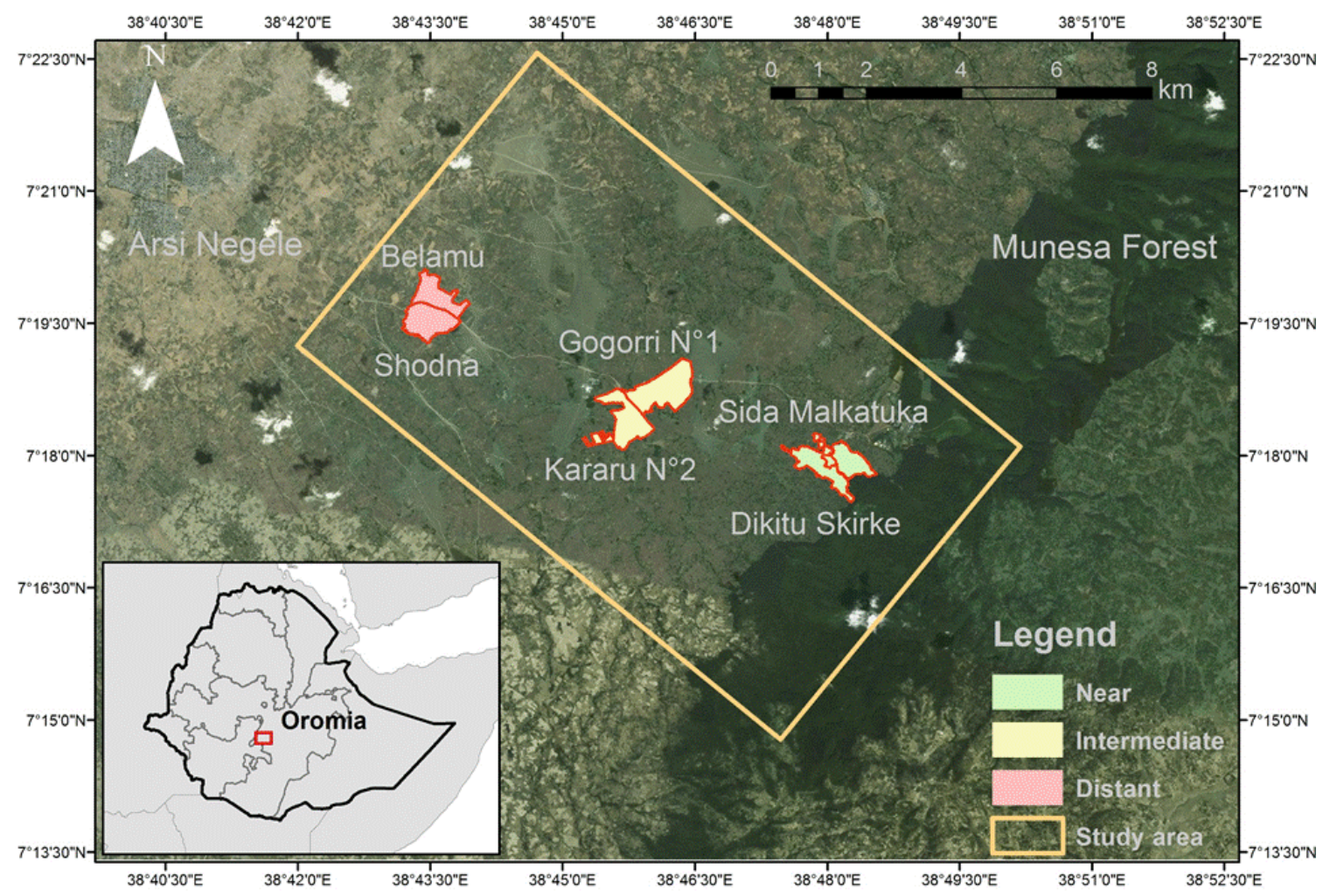

decreasing distance from a main road and market (town of Arsi Negele), we tested the existence of this fifth pathway. This area was selected because forest food was seldom consumed, and the sale of nontimber forest products is rare (the sale of forest fuelwood, for example, is prohibited); i.e., forests did not make a significant contribution to dietary diversity through the four other pathways described.

\section{METHODS}

\section{Study area}

The study was conducted in the Woreda (district) of Arsi-Negele, located in the Oromia region of Ethiopia. The study area (Fig. 1) covers approximately $100 \mathrm{~km}^{2}$ between $38^{\circ} 42.14^{\prime}$ and $38^{\circ} 49.92^{\prime}$ East and $7^{\circ} 15.05^{\prime}$ and $7^{\circ} 22.57^{\prime}$ North; it also borders the state forest of Munesa, and encompasses parts of three kebeles (subdistricts): Ashooka, Bombaso Regi, and Gambelto, in which a total of six villages were studied (Duriaux and Baudron 2016). The study area is located between 2050 and $2214 \mathrm{~m}$ above sea level. Its climate is subhumid and is characterized by a mean annual rainfall of $1075 \mathrm{~mm}$ per year (18 years average) and a mean annual temperature of $15^{\circ} \mathrm{C}(16$ years average). Three seasons are clearly defined: a short rainy season from March to May, a long rainy season from July to September, and a dry season from October to February (winter). The natural vegetation is classified as dry Afromontane forest (Tesfaye 2007). Inhabitants belong to the Oromo ethnic group and are almost exclusively of Islamic faith. Until the land reform that took place during the first years of the Marxist-Leninist regime (from 1974 to 1991), the landscape was largely forested and people were mainly pastoralists. The land was owned by nonresident landlords who seldom used the land itself. Resident tenants were only allowed to cultivate very small fields. Today, the study area outside Munesa Forest has been largely deforested. Mixed crop-livestock farming is the main economic activity. Wheat (Triticum sp. L.), maize (Zea mays L.), and potato (Solanum tuberosum L.) are the main crops, followed by enset (Ensete ventricosum (Welw.) Cheesman) and faba bean (Vicia faba L.). Most farmers keep livestock, such as cattle, sheep, goats, horses, donkeys, and chickens.

The Sida Malkatuka village and Dikitu Shirke village (in Ashooka kebele) border the state forest of Munesa (Fig. 1), and their residents have access to it for grazing and collection of fuelwood (Duriaux and Baudron 2016). These villages form a zone that we refer to as "near." Gogorri Lako Toko village (in Ashooka kebele) and Kararu Lakobsa Lama village (in Bombaso Regi kebele) are located about $3 \mathrm{~km}$ away from Munesa Forest (Fig. 1) and do not have access to it. They do have access to a large communal grazing area for livestock grazing and fuelwood collection (Duriaux and Baudron 2016). These villages form a zone that we refer to as "intermediate." Shodna village and Belamu village (in Gambelto kebele) are located about $7 \mathrm{~km}$ away from Munesa Forest (Fig. 
Fig. 2. (a) Food security (number of months for which households reported to have adequate food provisioning), (b) household diet diversity score (mean number of food groups [0-11] consumed daily during a week of recall), and (c) scores (number of days during a week a household consumes a particular food group) for 11 food groups in the three zones of the study area (near, intermediate, and distant to Munesa Forest). Bars represent standard deviations. $\chi^{2}$ and $P$ values are given for Kruskal-Wallis tests (comparison of medians). For a given food group, the presence of a star indicates statistically significant differences in the medians of the three zones. (HDDS: household diet diversity score; Cereals: cereals, grains, and cereal products; Roots: roots and tubers; Animal prod: meat and animal products; Milk prod: milk and milk products; Sugar prod: sugar, sugar products, and honey; Spices: spices and condiments; Snack: snack and processed foods).
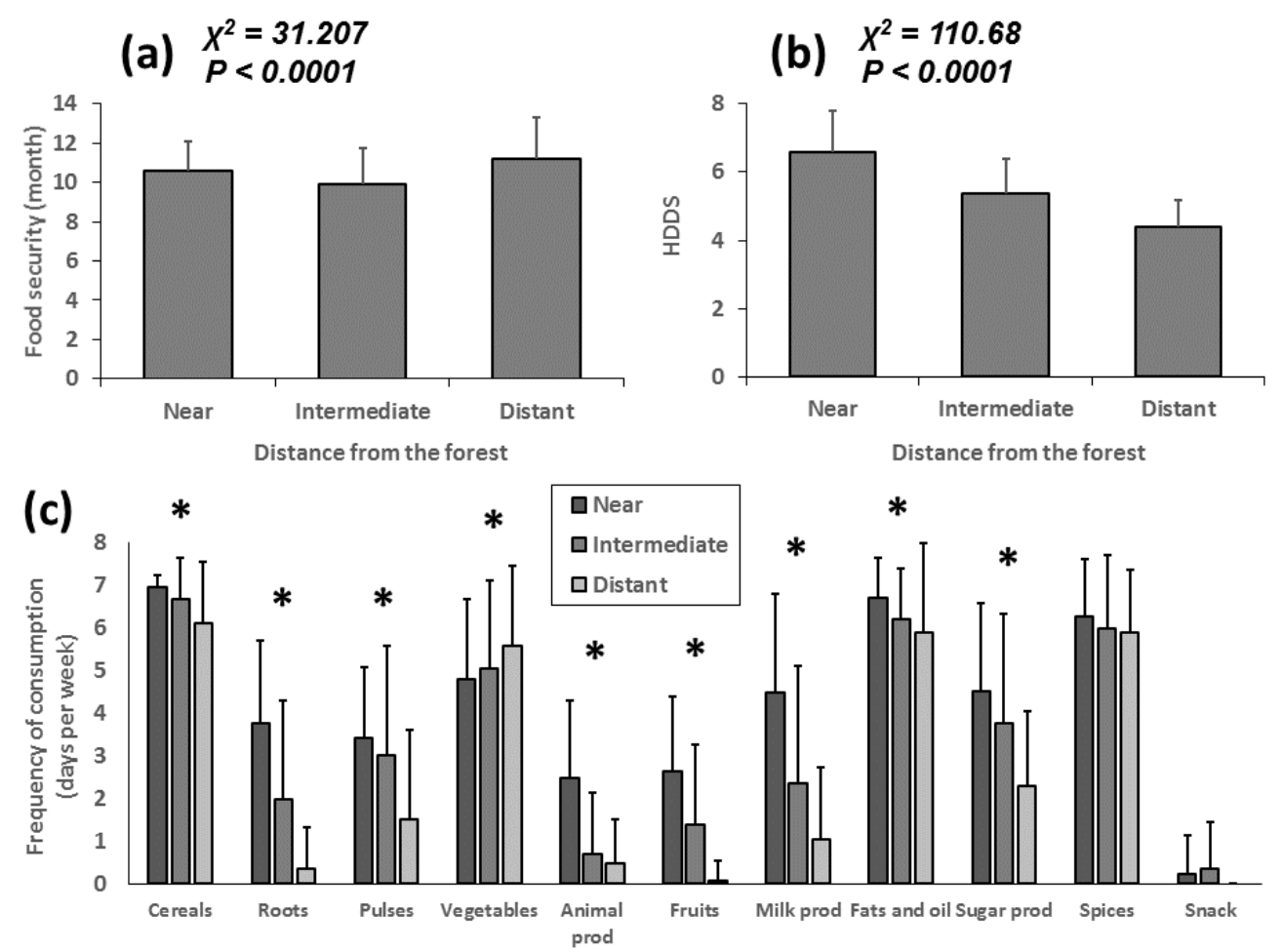

1). They do not have access to the forest or to any other common land for livestock grazing and fuelwood collection (Duriaux and Baudron 2016). These villages form a zone that we refer to as "distant." The near, intermediate, and distant zones are located about 16, 11.5, and $6.5 \mathrm{~km}$ away from the main market of Arsi Negele town, respectively (Fig. 1).

\section{Data sources and sampling}

Between December 2014 and February 2015, the head of each household in the study area-266 households in total ( 88 in the near zone, 97 in the intermediate zone, and 81 in the distant zone) -was interviewed using a standardized questionnaire that addressed household composition, dietary diversity, food security, crop and livestock management, and forest use. Questionnaires were administered only when consent was granted verbally. To asses dietary diversity, the Food and Agriculture Organization of the United Nations' household diet diversity tool (Kennedy et al. 2010) was adapted to capture the frequency of consumption of 11 food groups (Fig. 2c) in the household during the seven days that preceded the survey. Food security was determined based on the number of months for which households reported to have adequate food provisioning (Bilinsky and Swindale 2007). The location (including elevation) of each interviewed household was recorded using a handheld global positioning system (GPS) Garmin Etrek 10.

Between May and September 2015, tree cover in the three zones was estimated by counting and measuring the diameter at breast height ([DBH] $135 \mathrm{~cm}$ from ground level) of all trees with a DBH $>10 \mathrm{~cm}$ that were located within a radius of $50 \mathrm{~m}$ from 24 sampling points per zone. Sampling points were selected by overlaying $150-$ $m$ grids on the map of the zone and randomly selecting 24 points.

To describe farm heterogeneity, a self-categorization exercise was conducted in each zone, each with a group of 50-60 community members who were representative of the diversity of community members in the kebele (in terms of gender, age, and wealth). Based on the criteria from these self-categorization exercises, three farm types were identified: crop-oriented farms (more than 1 ha of farmland and less than four adult cattle per hectare of farmland), livestock-oriented farms (at least four adult cattle per hectare of farmland), and resource-poor farms (1 ha of farmland or less, 
Table 1. Summary of the main variables assessed, their units, the methods of assessment, and the size of the samples $(N)$.

\begin{tabular}{|c|c|c|c|}
\hline Variables & Unit & Method & $N$ \\
\hline Sex of the head of the household & Male/Female & Survey & 266 \\
\hline Age of the head of the household & No. & Survey & 266 \\
\hline Family size & No. & Survey & 266 \\
\hline Head of the household schooled & $0 / 1$ & Survey & 266 \\
\hline Tertiary education & $0 / 1$ & Survey & 266 \\
\hline Remittances & $0 / 1$ & Survey & 266 \\
\hline Paid work & $0 / 1$ & Survey & 266 \\
\hline Year the land was cleared & No. & Survey & 266 \\
\hline Year the household started farming & No. & Survey & 266 \\
\hline Food security & No. months & Survey & 266 \\
\hline Score per food group & No. days per week & Survey & 266 \\
\hline Presence of a homegarden & $0 / 1$ & Survey & 266 \\
\hline Diversity in homegarden & No. crop species & Survey & 266 \\
\hline Presence of enset in homegarden & $0 / 1$ & Survey & 266 \\
\hline Oxen and bulls & No. & Survey & 266 \\
\hline Cows & No. & Survey & 266 \\
\hline Steers and heifers & No. & Survey & 266 \\
\hline Calves & No. & Survey & 266 \\
\hline Donkeys & No. & Survey & 266 \\
\hline Beehives & No. & Survey & 266 \\
\hline Elevation of each farming household & Meters above sea level & GPS measurement & 266 \\
\hline Diameter at breast height of all trees within $50-\mathrm{m}$ radius & $\mathrm{m}^{2} \mathrm{ha}^{-1}$ & Tree survey & 96 \\
\hline Area of each field & ha & GPS measurement & 27 \\
\hline Production per crop & $\mathrm{kg}$ & Detailed characterization & 27 \\
\hline Seasonal milk production & L day $^{-1}$ & Detailed characterization & 27 \\
\hline Fuelwood from the forest and other common lands & $\%$ total fuel & Detailed characterization & 27 \\
\hline Fuelwood from the farm & $\%$ total fuel & Detailed characterization & 27 \\
\hline Dung used as fuel & $\%$ total fuel & Detailed characterization & 27 \\
\hline Crop residues used as fuel & $\%$ total fuel & Detailed characterization & 27 \\
\hline Purchased fuelwood & $\%$ total fuel & Detailed characterization & 27 \\
\hline Feed from the forest and other common lands & $\%$ total feed & Detailed characterization & 27 \\
\hline Feed from the farm (crop residue and "weeds") & $\%$ total feed & Detailed characterization & 27 \\
\hline Purchased feed & $\%$ total feed & Detailed characterization & 27 \\
\hline Manure applied & $\mathrm{kg}$ year $^{-1}$ & Detailed characterization & 27 \\
\hline Seasonal milk production & L day ${ }^{-1}$ & Empirical measurement & 9 \\
\hline Seasonal fuel consumption & kg dry matter day ${ }^{-1}$ & Empirical measurement & 9 \\
\hline Distance to nearest forest patch $>0.5$ ha & $\mathrm{m}$ & Remote sensing & 266 \\
\hline Distance to nearest forest patch $>0.25$ ha & $\mathrm{m}$ & Remote sensing & 266 \\
\hline Distance to nearest grassland patch $>0.5$ ha & $\mathrm{m}$ & Remote sensing & 266 \\
\hline Distance to nearest grassland patch $>0.25$ ha & $\mathrm{m}$ & Remote sensing & 266 \\
\hline Distance to nearest road & $\mathrm{m}$ & Remote sensing & 266 \\
\hline
\end{tabular}

and less than four adult cattle per hectare of farmland). A stratified subsample of nine farms was selected in each zone (27 farms in total) for detailed characterization. For each selected farm, the detailed characterization produced three main outputs: a resource flow map, resource use calendars, and a timeline (Geifus 2008, Giller et al. 2011). In addition, the area of each field was measured using a handheld GPS Garmin Etrek 10.

Empirical measurements were collected in nine of the 27 farms (one farm per type and per zone, selected randomly): daily fuel consumption (once in March 2015 and once in August 2015), and milk production over a period of seven days (once in March 2015 and once in September 2015).

Current land use was calculated from classified RapidEye imagery. Four tiles of RapidEye 3A imagery (5-m resolution) taken in January 2015 were used to classify the landscape into croplands and bare soil, enset homegardens, grassland, natural forest and tree cover, tree plantations, and woodlots. A combination of object-based and maximum likelihood supervised classification was performed to distinguish between these classes. Training sites were verified using a combination of high-resolution imagery from Google Earth and ground verification via onsite fieldwork. Furthermore, enset homegarden patches were digitized using high-resolution imagery from Google Earth. The minimum mapping unit was set at the size of the smallest spatial resolution $(5 \mathrm{~m} \times 5 \mathrm{~m})$. Distances between each farming household and Munesa Forest, the nearest forest patch of at least $0.5 \mathrm{ha}$, the nearest forest patch of at least $0.25 \mathrm{ha}$, the nearest grassland patch of at least 0.5 ha, the nearest grassland patch of at least $0.25 \mathrm{ha}$, and the nearest road were then calculated. For this, the nearest Euclidean distance to these features - selected via query-was calculated and extracted for each farming household point. Table 1 summarizes the main variables assessed and the methods of assessment. 


\section{Calculations and data analysis}

For each household, the household diet diversity score was calculated as the mean number of food groups [0-11] consumed daily during a week of recall (Kennedy et al. 2010). Food security was calculated as the number of months for which households reported to have adequate food provisioning (Bilinsky and Swindale 2007). Tree cover was estimated for each tree count point by the basal area, calculated by dividing the sum of the section area of all trees (at breast height) by the total surface area. Yields were calculated by dividing the quantity of grain, tuber, or fresh product harvested (as recalled by farmers during the household interview) by the area of the corresponding field (as measured using a GPS) and multiplying it by the estimated dry matter content of the product harvested, using standard values from Feedipedia and USDA web databases (http://www.feedipedia. org/; https://ndb.nal.usda.gov/ndb/search). To compare livestock density in the different zones and farms, the livestock numbers reported in the survey were converted into tropical livestock units (TLU), using a value of $250 \mathrm{~kg}$ live weight for one TLU (Houérou and Hoste 1977). Following the method of Gryseels (1988), oxen and bulls were assumed to be equivalent to $1.1 \mathrm{TLU}$, cows to 0.8 TLU, steers and heifers to 0.5 TLU, calves to 0.2 TLU, sheep and goats to $0.09 \mathrm{TLU}$, horses to $0.7 \mathrm{TLU}$, and donkeys to $0.36 \mathrm{TLU}$. Milk production was estimated from farmer recall, and was compared with empirical measurements. Meat production was estimated from recalled annual animal sales and animal slaughtering (for self-consumption). For crop and livestock products, conversion to energy content was undertaken using standard values from Feedipedia and USDA web databases (http://www.feedipedia.org/; https://ndb.nal.usda.gov/ndb/search).

\section{Statistical analysis}

Quantitative data were tested for normal distribution using Shapiro-Wilk normality tests. When testing for differences between zones, Fisher tests were used to compare means of quantitative data, and Kruskal-Wallis (nonparametric) tests were used for medians. For the qualitative data, proportions were compared using Chi-square tests. Correlations between quantitative variables were tested using Kendall's tau coefficient, and logit models were used to test correlations between quantitative and qualitative variables.

Generalized linear models were used to assess the source of variability in food security, dietary diversity, frequency of consumption of the 11 food groups, presence of a homegarden in the farm, and crop diversity in homegardens (for the subset of farms that owned a homegarden). A logit distribution was used when presence of a homegarden in the farm was used as a response variable, and a Gamma distribution was used when all other variables were used as response variables. Model 1 aimed at testing the effect of farm location (e.g., zone), when controlling for demographic variables (e.g., family size) and structural variables (e.g., farm area). Model 2 aimed at testing the effect of functional variables (e.g., livestock ownership) when controlling for demographic variables and structural variables. Models were constructed as follows:

$$
\begin{aligned}
\text { (Model 1) } & \\
\mathrm{Y}_{\mathrm{ijklmn}}=\alpha+\beta \mathrm{ZN}_{\mathrm{i}} & +\gamma \mathrm{EL}+\delta \mathrm{DF} 0.5+\varepsilon \mathrm{DF} 0.25+\zeta \mathrm{DG} 0.5 \\
& +\eta \mathrm{DG} 0.25+\theta \mathrm{DR}+\mathrm{sSX} \mathrm{j}_{\mathrm{j}}+\kappa \mathrm{AG}+\lambda \mathrm{FS} \\
& +\mu \mathrm{ED}_{\mathrm{k}}+\nu \mathrm{TE}_{\mathrm{l}}+\xi \mathrm{RE}_{\mathrm{m}}+\mathrm{oPW}_{\mathrm{n}}+\pi \mathrm{YC} \\
& +\rho \mathrm{YS}+\varsigma \mathrm{FA}+\mathrm{R}
\end{aligned}
$$

(Model 2)

$$
\begin{aligned}
\mathrm{Y}_{\text {ijklmnopqrstuvw }}= & \alpha+\beta \mathrm{HG}_{\mathrm{i}}+\gamma \mathrm{CA}+\delta \mathrm{SG}+\varepsilon \mathrm{EQ}+\zeta \mathrm{BH} \\
& +\eta \mathrm{CH}+\theta \mathrm{SX}_{\mathrm{j}}+\mathrm{LG}+\kappa \mathrm{FS}+\lambda \mathrm{ED}_{\mathrm{k}} \\
& +\mu \mathrm{TE}_{\mathrm{l}}+\nu \mathrm{RE}_{\mathrm{m}}+\xi \mathrm{PW}_{\mathrm{n}}+\mathrm{oYC}+\pi \mathrm{YS} \\
& +\mathrm{R}
\end{aligned}
$$

where $Y_{\mathrm{ijklmn}}$ represents food security, dietary diversity, frequency of consumption of food groups, presence or absence of homegarden, or crop diversity of homegarden; $\mathrm{ZN}_{\mathrm{i}}$ is the $\mathrm{i}^{\text {th }}$ zone (near, intermediate, or distant); EL is the elevation; DF0.5 is the distance to the nearest patch of forest of at least 0.5 ha; DF 0.25 is the distance to the nearest patch of forest of at least $0.25 \mathrm{ha}$; DG0.5 is the distance to the nearest patch of grassland of at least $0.5 \mathrm{ha}$; DG0.25 is the distance to the nearest patch of grassland of at least $0.25 \mathrm{ha}$; DR is the distance to the nearest road; $\mathrm{SX}_{\mathrm{j}}$ is the $j^{\text {th }}$ sex of the head of the household, AG is the age of the head of the household; FS is the family size of the household; $E_{k}$ is the $\mathrm{k}^{\text {th }}$ level of education of the head of the household (presence or absence); $\mathrm{TE}_{1}$ is the $\mathrm{l}^{\text {th }}$ level of tertiary education of the head of the household (presence or absence); $\mathrm{RE}_{\mathrm{m}}$ is the $\mathrm{m}^{\text {th }}$ level of remittances received by the household (presence or absence); $\mathrm{PW}_{\mathrm{n}}$ is the $\mathrm{n}^{\text {th }}$ level of paid work of the head of the household (presence or absence); YC is the year the land was cleared; YS is the year farming started; FA is the farm area; $\mathrm{HG}_{\mathrm{i}}$ is the $\mathrm{i}^{\text {th }}$ level of homegarden presence on the farm (presence or absence); $\mathrm{CA}$ is cattle ownership (in TLU); SG is sheep and goats ownership (in TLU); EQ is equine ownership (in TLU); $\mathrm{BH}$ is the number of beehives owned; $\mathrm{CH}$ is the number of chicken owned; and $\mathrm{R}$ is the residual; $\alpha, \beta, \gamma, \theta, \mathrm{l}, \lambda, \mu, \xi, o, \pi, \rho$, and $\varsigma$ represent fixed effects values. A probability of 0.05 was used to test the significance of each factor. In each model, factors that had a $t$ value less than 0.1 were removed. Two-way interactions between the factor "zone" and other factors on which "zone" had a significant influence were added in Model 1. Similarly, two-way interactions between the factor "homegarden" and other factors on which "homegarden" had a significant influence were added in Model 2. All analyses were conducted using R software (version 2.14.1, Foundation for Statistical Computing, 2011).

\section{RESULTS}

\section{General characterization of the gradient}

Tree cover - as assessed by the mean basal area-decreased with increasing distance from Munesa Forest: $5.11 \pm 4.21,2.13 \pm 1.69$, and $0.63 \pm 0.87 \mathrm{~m}^{2} \mathrm{ha}^{-1}$ in the near, intermediate, and distant zones, respectively $\left(\chi^{2}=34.535, P<0.0001\right)$. Farm elevation-as measured by handheld GPS - decreased with increasing distance from Munesa Forest (Table 2). From the remote sensing analysis, distance to a patch of forest (excluding Munesa Forest), whether small (minimum area of $0.25 \mathrm{ha}$ ) or large (minimum size of 0.5 ha), increased with increasing distance from Munesa Forest (Table 2). Farms in the intermediary zone were closer to small (minimum area of $0.25 \mathrm{ha}$ ) and large (minimum size of $0.5 \mathrm{ha}$ ) patches of grassland compared with farms in the two other zones (Table 2). Conversely, farms in the near zone were closer to a road than farms in the two other zones (Table 2).

The analysis of the demographic data collected through household survey revealed that the age of the head of the household, the year the household started farming, the percentage of female-headed households, the percentage of households with 
Table 2. Comparison of locational, demographic, and farming system characteristics of the farming households in the three zones of the study area (near, intermediate, and distant to Munesa Forest). Units are given in parentheses. Standard errors are given after the " $\pm ”$ signs. $\chi^{2}$ and $P$ values are given for Kruskal-Wallis tests that compared medians between the three zones (TLU: tropical livestock unit).

\begin{tabular}{|c|c|c|c|c|c|}
\hline Farm/household characteristics & Near & Intermediate & Distant & $x^{2}$ & $P$ \\
\hline Elevation (meters above sea level) & $2176.4 \pm 14.5$ & $2102.6 \pm 9.0$ & $2070.3 \pm 7.2$ & 231.59 & $<0.0001$ \\
\hline Distance to Munesa Forest (m) & $91.7 \pm 129.8$ & $2715.6 \pm 296.4$ & $6766.5 \pm 276.5$ & 231.5 & $<0.0001$ \\
\hline $\begin{array}{l}\text { Distance to nearest forest patch }>0.5 \text { ha } \\
(\mathrm{m})\end{array}$ & $8.8 \pm 12.4$ & $21.1 \pm 29.6$ & $269.9 \pm 175.5$ & 163.87 & $<0.0001$ \\
\hline $\begin{array}{l}\text { Distance to nearest forest patch }>0.25 \text { ha } \\
(\mathrm{m})\end{array}$ & $8.8 \pm 12.4$ & $17.4 \pm 23.7$ & $167.0 \pm 123.4$ & 140.74 & $<0.0001$ \\
\hline $\begin{array}{l}\text { Distance to nearest grassland patch }>0.5 \\
\text { ha }(\mathrm{m})\end{array}$ & $137.0 \pm 120.0$ & $47.5 \pm 72.6$ & $143.3 \pm 81.2$ & 60.019 & $<0.0001$ \\
\hline $\begin{array}{l}\text { Distance to nearest grassland patch }>0.25 \\
\text { ha }(\mathrm{m})\end{array}$ & $61.6 \pm 62.5$ & $17.0 \pm 25.4$ & $49.1 \pm 53.3$ & 39.309 & $<0.0001$ \\
\hline Distance to nearest road (m) & $641.2 \pm 809.7$ & $740.4 \pm 768.4$ & $538.9 \pm 745.8$ & 7.0494 & $<0.05$ \\
\hline Age of the head of the household & $43.2 \pm 13.5$ & $41.0 \pm 13.3$ & $42.0 \pm 13.8$ & 1.439 & n.s. \\
\hline Family size & $8.5 \pm 4.8$ & $6.2 \pm 3.6$ & $5.3 \pm 2.5$ & 22.347 & $<0.0001$ \\
\hline Year land was cleared & $1964 \pm 12$ & $1965 \pm 13$ & $1960 \pm 14$ & 10.315 & $<0.01$ \\
\hline Year the household started farming & $1999 \pm 13$ & $2000 \pm 12$ & $1999 \pm 14$ & 0.84818 & n.s. \\
\hline Farm area (ha) & $1.98 \pm 7.99$ & $0.98 \pm 0.68$ & $0.86 \pm 0.57$ & 10.667 & $<0.005$ \\
\hline All livestock (TLU) & $3.49 \pm 3.02$ & $2.23 \pm 1.98$ & $1.86 \pm 2.39$ & 19.999 & $<0.0001$ \\
\hline Cattle (TLU) & $2.94 \pm 2.69$ & $1.88 \pm 1.80$ & $1.68 \pm 2.27$ & 15.235 & $<0.0005$ \\
\hline Sheep and goats (TLU) & $0.25 \pm 0.33$ & $0.10 \pm 0.18$ & $0.03 \pm 0.12$ & 43.129 & $<0.0001$ \\
\hline Equines (TLU) & $0.27 \pm 0.40$ & $0.21 \pm 0.33$ & $0.13 \pm 0.22$ & 5.8336 & $<0.1$ \\
\hline Beehives (number) & $0.62 \pm 1.94$ & $0.47 \pm 1.83$ & $0.05 \pm 0.45$ & 7.5423 & $<0.05$ \\
\hline Chicken (number) & $2.98 \pm 3.52$ & $4.09 \pm 5.02$ & $2.14 \pm 3.85$ & 11.573 & $<0.005$ \\
\hline $\begin{array}{l}\text { Diversity in homegarden (number of } \\
\text { species) }\end{array}$ & $2.88 \pm 1.59$ & $2.10 \pm 2.04$ & $0.88 \pm 1.31$ & 49.845 & $<0.0001$ \\
\hline Female-headed households ( $\%$ farms) & 23.3 & 25.0 & 25.0 & 1.3278 & n.s. \\
\hline Homestead with a metal roof ( $\%$ farms) & 52.3 & 53.1 & 36.3 & 5.9226 & $<0.1$ \\
\hline Head of the household schooled ( $\%$ farms) & 76.7 & 74.0 & 58.8 & 8.7184 & $<0.05$ \\
\hline Tertiary education ( $\%$ farms) & 27.9 & 27.1 & 7.5 & 7.4487 & $<0.05$ \\
\hline Remittances ( $\%$ farms) & 7.0 & 11.5 & 0.0 & 11.826 & $<0.005$ \\
\hline Paid work ( $\%$ farms) & 16.3 & 17.7 & 19.0 & 0.45221 & n.s. \\
\hline Homegarden ( $\%$ farms) & 85.5 & 62.4 & 38.5 & 38.13 & $<0.0001$ \\
\hline $\begin{array}{l}\text { Presence of enset ( } \% \text { farms with } \\
\text { homegarden) }\end{array}$ & 100.0 & 98.3 & 43.3 & 16.407 & $<0.0005$ \\
\hline
\end{tabular}

a metal roof (proxy of wealth), and the proportion of households involved in paid work did not differ significantly between the three zones (Table 2). Conversely, family size tended to decrease with increasing distance from Munesa Forest, while the percentage of household heads having received education (any form of education, or tertiary education) and the percentage of households receiving remittances were lower in the distant zone compared with the two other zones (Table 2).

Characteristics of farms and farming systems that were collected through the household survey revealed that farms in the distant zone tended to have been cleared a few years earlier than farms in the other two zones (Table 2). Farm area and livestock ownership tended to decrease significantly with increasing distance from Munesa Forest (Table 2). The same trend was observed for all livestock types except chicken: i.e., cattle, sheep and goats, equines, and beehives. Chicken ownership in the intermediate zone was significantly higher than in the two other zones. The percentage of farms with a homegarden decreased significantly with increasing distance from Munesa Forest, as did the crop diversity in these homegardens and the percentage of these homegardens that contained enset (Table 2).

\section{Dietary diversity and food security along the gradient}

Food security, in terms of months of adequate household food provisioning, was lower in the intermediate zone compared with the two other zones, although the difference was less than 1 month $\left(10.6 \pm 1.5,9.9 \pm 1.8\right.$, and $11.2 \pm 2.1$ months year $^{-1}$ in the near, intermediate, and distant zones, respectively) (Fig. 2a). Households in the near zone had more diverse diets than households in the distant zone (Fig. 2b). Households in the intermediate zone ranked between households in the two other zones (Fig. 2b). Differences in household dietary diversity scores between the three zones were much larger than differences in food security. The difference in household diet diversity scores was explained by the more frequent consumption in the near zone of every food group except "vegetables"; the frequency of consumption of "spices and condiments" did not differ between the three zones (Fig. 2c). Follow-up interviews revealed that these food groups were predominantly sourced from the market, while households sourced the other food groups predominantly from their own agricultural production. Consumption of wild foods from the forest was seldom reported in the dietary recall, and follow-up interviews confirmed that this happened only very rarely in this setting, and involved mainly young herders guarding livestock in the forest and occasionally picking wild fruits. 
Table 3. Summary of the results of Model 1 for explaining the variability in food security (months of adequate food provisioning) and dietary diversity (household dietary diversity score). Significant effects $(P<0.05)$ are shown in bold.

\begin{tabular}{|c|c|c|c|c|}
\hline \multirow[t]{2}{*}{ Model variables } & \multicolumn{2}{|c|}{ Food security } & \multicolumn{2}{|c|}{ Dietary diversity } \\
\hline & $t$ value & $P$ value & $t$ value & $P$ value \\
\hline Intercept & 0.272 & 0.7850 & -1.116 & 0.2470 \\
\hline Zone & -0.068 & 0.9460 & 2.422 & 0.0162 \\
\hline Elevation & 1.275 & 0.2020 & 2.505 & 0.0129 \\
\hline Distance to nearest forest patch $>0.5$ ha & & & 1.178 & 0.2400 \\
\hline Distance to nearest forest patch $>0.25$ ha & -0.930 & 0.3520 & -1.566 & 0.1188 \\
\hline Distance to nearest grassland patch $>0.5$ ha & & & -0.496 & 0.6204 \\
\hline Distance to nearest grassland patch $>0.25$ ha & -0.577 & 0.5640 & 1.163 & 0.2461 \\
\hline Distance to nearest road & & & 1.196 & 0.2328 \\
\hline Sex of the head of the household & 0.258 & 0.7960 & 0.221 & 0.8255 \\
\hline Age of the head of the household & 0.467 & 0.6400 & -1.077 & 0.2827 \\
\hline Family size & & & -1.003 & 0.3171 \\
\hline Head of the household schooled & 0.220 & 0.8260 & 1.086 & 0.2787 \\
\hline Tertiary education & 0.671 & 0.5020 & -3.480 & 0.0006 \\
\hline Remittances & -0.733 & 0.4630 & -0.509 & 0.6112 \\
\hline Paid work & -0.419 & 0.6750 & & \\
\hline Year land was cleared & -0.824 & 0.4100 & 0.474 & 0.6359 \\
\hline Year the household started farming & 0.525 & 0.6000 & -1.062 & 0.2895 \\
\hline Farm area & 0.758 & 0.4490 & 0.926 & 0.3555 \\
\hline Zone $\times$ Elevation & -0.478 & 0.6330 & -2.904 & 0.0040 \\
\hline Zone $\times$ Distance to nearest forest patch $>0.5$ ha & & & -1.229 & 0.2203 \\
\hline Zone $\times$ Distance to nearest forest patch $>0.25$ ha & 0.996 & 0.3190 & 1.549 & 0.1226 \\
\hline Zone $\times$ Distance to nearest grassland patch $>0.5$ ha & & & -0.149 & 0.8816 \\
\hline Zone $\times$ Distance to nearest grassland patch $>0.25$ ha & & & -0.707 & 0.4803 \\
\hline Zone $\times$ Family size & -0.952 & 0.3410 & 1.041 & 0.2988 \\
\hline Zone $\times$ Head of the household schooled & 0.565 & 0.5720 & -2.097 & 0.0370 \\
\hline Zone $\times$ Tertiary education & -0.681 & 0.4960 & 2.752 & 0.0064 \\
\hline Zone $\times$ Remittances & & & 0.793 & 0.4288 \\
\hline \multicolumn{5}{|l|}{ Zone $\times$ Paid work } \\
\hline Zone $\times$ Year land was cleared & 0.473 & 0.6360 & -0.371 & 0.7110 \\
\hline Zone $\times$ Farm area & -0.838 & 0.4020 & -0.951 & 0.3427 \\
\hline
\end{tabular}

When testing for the effect of farm location in Model 1 (while controlling for demographic and structural variables), the zone in which a particular farm was located had no effect on food security but had a statistically significant effect on dietary diversity (Table 3 ). The effects of zone on dietary diversity appeared to be nonlinear because the two-way interactions between zone and elevation and between zone and education of the head of the household were significant in Model 1. None of the variables that described the farm location and which were tested in Model 1 had a significant effect on food security. The factor zone and/or the interaction between zone and elevation were also significant when using frequency of consumption as a response variable in Model 1 for the following food groups: roots and tubers; pulses; meat and animal products; fruits; milk and milk products; sugar, sugar products, and honey; and snack and processed foods (Appendixes 1 and 3). The effect of proximity to the forest was positive for all these food groups except sugar, sugar products, and honey, and snack and processed foods, for which it was negative.

When testing for the effect of functional variables in Model 2 (while controlling for demographic and structural variables), the presence/absence of a homegarden and livestock ownership (in particular, ownership of sheep and goats and beehives) had a significant effect on dietary diversity but no effect on food security (Table 4). The two-way interaction between the presence/absence of a homegarden and the number of beehives was also significant in Model 2. None of the variables tested in Model 2 had a significant effect on food security. The factor homegarden and/ or the interaction between homegarden and any livestock category except chicken (cattle, sheep and goats, or equines) were also significant and positive in Model 2 when using frequency of consumption as a response variable for the following food groups: roots and tubers; pulses; vegetables; meat and animal products; fruits; milk and milk products; sugar, sugar products, and honey; and snack and processed foods (Appendices 2 and 4).

Functioning of the farms along the gradient: homegarden, biomass use, and crop and livestock productivity

When testing for the effect of farm location (Model 1), the interaction between zone and family size had a significant effect on the presence/absence of a homegarden in the farm (Annexe 5, Fig. 3a). Other significant variables were family size and farm area. When using the crop diversity in the homegarden as a response variable, the interaction between zone and distance to the nearest grassland patch of at least 0.25 ha was significant in Model 1 (Appendix 5). Other significant variables were distance to the nearest grassland patch of at least $0.5 \mathrm{ha}$, farm area, and the interaction between zone and farm area. When testing for the effect of functional variables (Model 2), livestock ownership (in particular, ownership of sheep and goats) had a significant effect on the presence/absence of a homegarden in the farm (Appendix 
Table 4. Summary of the results of Model 2 for explaining the variability in food security (months of adequate food provisioning) and dietary diversity (household dietary diversity score). Significant effects $(P<0.05)$ are shown in bold (Homegarden: presence of absence of a homegarden; TLU: tropical livestock unit).

\begin{tabular}{|c|c|c|c|c|}
\hline \multirow[t]{2}{*}{ Model variables } & \multicolumn{2}{|c|}{ Food security } & \multicolumn{2}{|c|}{ Dietary diversity } \\
\hline & $t$ value & $P$ value & $t$ value & $P$ value \\
\hline Intercept & 0.817 & 0.4140 & 1.761 & 0.0795 \\
\hline Homegarden & & & -4.223 & 0.0000 \\
\hline Cattle (TLU) & 1.027 & 0.3040 & -0.382 & 0.7026 \\
\hline Sheep and goat (TLU) & 1.017 & 0.3090 & -2.579 & 0.0105 \\
\hline Equines (TLU) & -1.299 & 0.1940 & & \\
\hline Beehives & -0.631 & 0.5280 & -2.139 & 0.0335 \\
\hline Chicken & 0.370 & 0.7120 & -0.764 & 0.4454 \\
\hline Family size & -1.155 & 0.2480 & -1.772 & 0.0776 \\
\hline Head of the household schooled & 1.338 & 0.1810 & -1.516 & 0.1308 \\
\hline Tertiary education & -0.292 & 0.7700 & -2.702 & 0.0074 \\
\hline Remittances & -0.956 & 0.3390 & -1.275 & 0.2035 \\
\hline Paid work & -0.464 & 0.6420 & 0.904 & 0.3669 \\
\hline Year land was cleared & -1.238 & 0.2160 & -0.866 & 0.3872 \\
\hline Year farming started & 0.851 & 0.3950 & -0.969 & 0.3335 \\
\hline Homegarden $\times$ Cattle (TLU) & -0.600 & 0.5480 & 0.140 & 0.8888 \\
\hline Homegarden $\times$ Sheep and goat (TLU) & -0.740 & 0.4590 & 1.934 & 0.5440 \\
\hline Homegarden $\times$ Equines $($ TLU) & 1.365 & 0.1720 & & \\
\hline Homegarden $\times$ Beehives & 0.695 & 0.4870 & 2.184 & 0.0299 \\
\hline Homegarden $\times$ Chicken & & & & \\
\hline
\end{tabular}

Fig. 3. Percentage of farming households with a small family ( $0-5$ people [pp]) or a large family (more than 5 people) and a homegarden in the three zones of the study area (near, intermediate, and distant to Munesa Forest), and (b) percentage of farming households with small livestock ownership (less than 1 tropical livestock unit [TLU]), medium livestock ownership (1-3 TLU), and large livestock ownership (more than 3 TLU), and a homegarden.
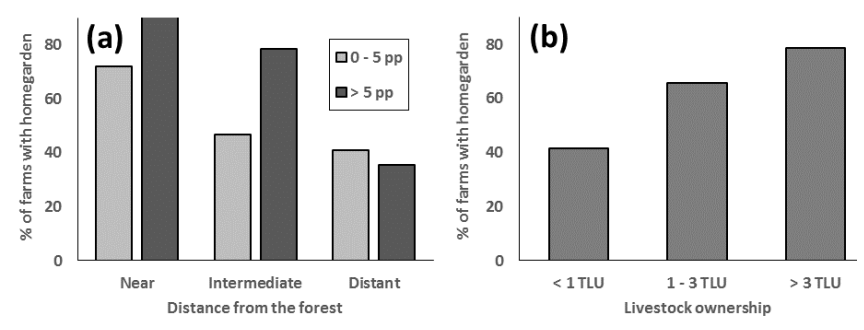

6, Fig. 3b). Other significant variables were family size and year that farming started. When using the crop diversity in the homegarden as a response variable, the presence/absence of enset was found to be overruling in Model 2. No other variable was significant. Livestock ownership had a statistically significant effect on the presence or absence of enset in the homegarden $(Z$ $=3.548, P<0.0005)$.

The quantity of biomass used as household fuel tended to decrease with increasing distance from Munesa Forest, but the differences were not statistically significant (Table 5). In addition, group interviews revealed that these differences had no effect on the food items households were or were not able to cook and consume. However, the composition of the household fuel changed with increasing distance from the forest. Closer to the forest, households used significantly more fuelwood from the forest (and other commons), while farther away from the forest, households used significantly more cattle dung as fuel (Table 5). Farmers in the distant zone also purchased fuelwood, while farmers closer to the forest were able to access free fuelwood, mostly from the farms in the intermediate zone, and mostly from Munesa Forest in the near zone (Fig. 4a).

Fig. 4. (a) Harvesting of firewood, (b) cattle grazing in Munesa Forest, and (c) section of Munesa Forest showing signs of degradation.

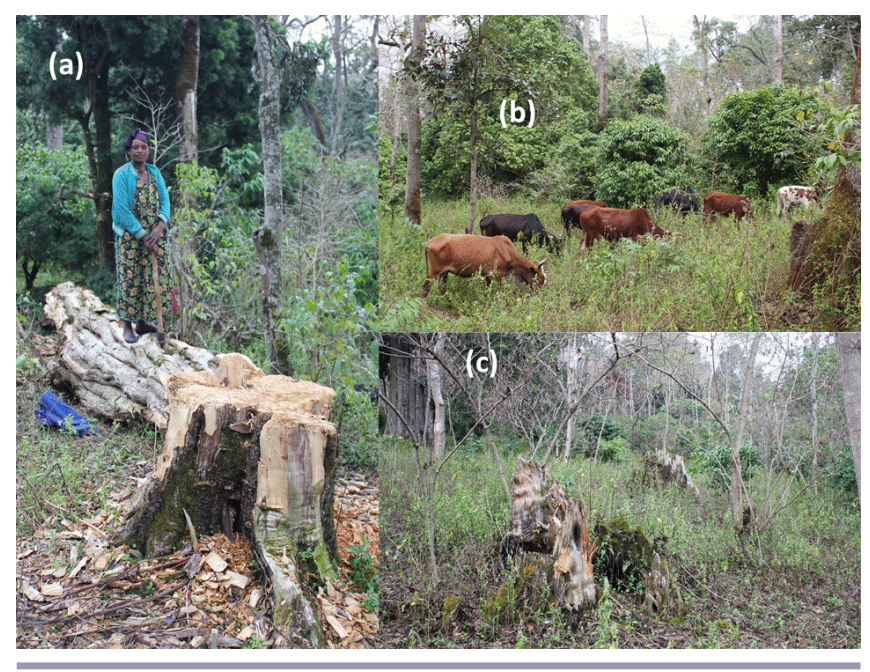

Similarly, the quantity of biomass used as livestock feed tended to be lower in the distant zone compared with the two other zones, but the differences were not statistically significant (Table 6). 
Table 5. Comparison of the mean quantity of biomass in $\mathrm{kg}$ household $^{-1}$ year $^{-1}$ from different sources used as household fuel in the three zones of the study area (near, intermediate, and distant to Munesa Forest). Standard errors are given after the " \pm " signs. $\chi^{2}$ and $P$ values are given for Kruskal-Wallis tests that compared medians between the three zones.

\begin{tabular}{|c|c|c|c|c|c|}
\hline Biomass used as fuel & Near & Intermediate & Distant & $x^{2}$ & $P$ \\
\hline Forest and common lands & $3257 \pm 1461$ & $407 \pm 978$ & $353 \pm 530$ & 16.911 & $<0.0001$ \\
\hline Crop residues and farm trees & $1055 \pm 1534$ & $2833 \pm 1032$ & $668 \pm 667$ & 10.444 & $<0.01$ \\
\hline Dung & $0 \pm 0$ & $72 \pm 144$ & $428 \pm 330$ & 13.695 & $<0.005$ \\
\hline Crop residues & $794 \pm 414$ & $760 \pm 305$ & $876 \pm 472$ & 0.20174 & n.s. \\
\hline Purchased & $0 \pm 0$ & $0 \pm 0$ & $510 \pm 524$ & 11.669 & $<0.005$ \\
\hline Total & $5106 \pm 1678$ & $4073 \pm 1443$ & $2835 \pm 954$ & 5.6257 & n.s. \\
\hline
\end{tabular}

However, the sources of feed for livestock differed significantly across the three zones. The quantity of biomass from the forest (and other commons) that was used as feed decreased significantly with increasing distance from Munesa Forest (Table 6), which is intensively used as a grazing area by farmers from the near zone (Fig. 4b). The quantity of biomass from the farm that was used as feed followed a similar trend, but the statistical significance of the differences was weak. The overall quantity of feed purchased in the three zones did not differ significantly. Total livestock ownership was significantly correlated to the quantity of biomass from the forest and other commons that was used as feed $(Z=$ 4.3191, $P<0.0001)$.

Summing the biomass flows from fuelwood and feed, Munesa Forest contributed an average of $6.13 \pm 2.90$ tons of biomass per farm and per year to farms in the near zone. The input of biomass from commons to farms in the other two zones was less than half that value $(2.72 \pm 1.05$ and $2.20 \pm 2.47$ tons per year in the intermediate and distant zones, respectively).

There was no difference between the three zones in the application rate of the two types of mineral fertilizer used in the area: diammonium phosphate $(F=0.454$, n.s. $)$ and urea $(F=0.761$, n. s.). However, farmers in the distant zone applied significantly less manure on their farms than did farmers in the two other zones $\left(908 \pm 853 \mathrm{~kg} \mathrm{farm}^{-1}, 771 \pm 717 \mathrm{~kg} \mathrm{farm}^{-1}\right.$, and $261 \pm 487 \mathrm{~kg} \mathrm{farm}^{-1}$ in the near, intermediate, and distant zone, respectively; $\chi^{2}=55.31$, $P<0.0001)$. Farms that did not use dung as fuel tended to apply more manure than did farms that used dung as fuel, although the statistical significance of the difference was moderate $\left(\chi^{2}=3.2056\right.$, $P<0.1$ ). The total crop productivity (calculated as the sum of all calories produced from crops within a year and divided by the total farm area) did not differ in the three zones $(34.2 \pm 9.7 \mathrm{GJ}$ $\mathrm{ha}^{-1}, 31.8 \pm 19.2 \mathrm{GJ} \mathrm{ha}^{-1}$, and $37.7 \pm 14.5 \mathrm{GJ} \mathrm{ha}^{-1}$ in the near, intermediate, and distant zones, respectively) (Fig. 5a). However, the total livestock productivity (calculated as the sum of calories produced from livestock within a year and divided by the total farm area) was significantly higher in the near zone compared with the two other zones $\left(2.62 \pm 1.60 \mathrm{GJ} \mathrm{ha}^{-1}, 0.97 \pm 0.73 \mathrm{GJ} \mathrm{ha}^{-1}\right.$, and $0.95 \pm 0.97 \mathrm{GJ} \mathrm{ha}^{-1}$ in the near, intermediate, and distant zones, respectively) (Fig. 5b).

\section{DISCUSSION}

This study illustrates indirect contributions, through flows of biomass, from Munesa Forest to the dietary diversity of surrounding farming households, and plays a pioneering role in unraveling such pathways (Fig. 6).
Fig. 5. (a) Mean crop productivity, and (b) mean livestock productivity of farms in the three zones of the study area (near, intermediate, and distant to Munesa Forest). Bars represent standard deviations. $F$ and $P$ values are given for the Fischer test (comparison of means), and $\chi^{2}$ and $P$ values are given for the Kruskal-Wallis tests (comparison of medians).
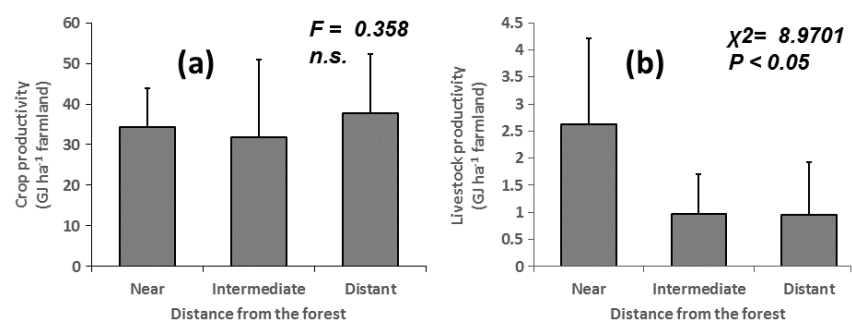

Fig. 6. Schematic representation of the effect of forest (and other commons) on the quantity and quality of crop and livestock products. The "+" signs show positive relationships; the "-" signs show negative relationships.

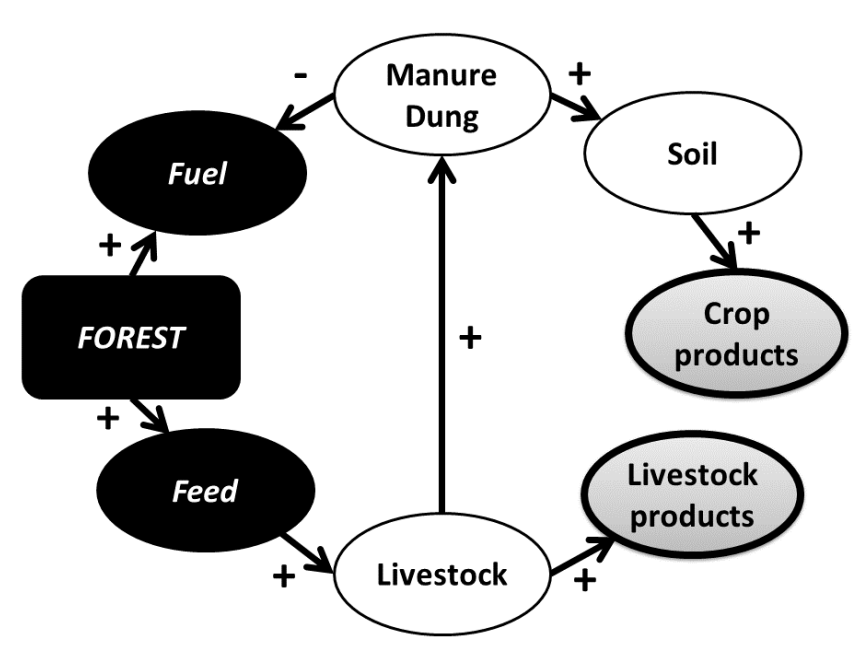


Table 6. Comparison of the mean quantity of biomass in $\mathrm{kg} \mathrm{farm}^{-1}$ year $^{-1}$ from different sources used as livestock feed in the three zones of the study area (near, intermediate, and distant to Munesa Forest). Standard errors are given after the “ \pm " signs. $\chi^{2}$ and $P$ values are given for Kruskal-Wallis tests that compared medians between the three zones.

\begin{tabular}{|c|c|c|c|c|c|}
\hline Biomass used as feed & Near & Intermediate & Distant & $x^{2}$ & $P$ \\
\hline Forest and common lands & $2876 \pm 2860$ & $1935 \pm 859$ & $306 \pm 471$ & 11.912 & $<0.005$ \\
\hline Crop residue and weeds & $5184 \pm 3646$ & $4640 \pm 3074$ & $2301 \pm 3630$ & 4.9749 & $<0.1$ \\
\hline Purchased & $143 \pm 311$ & $348 \pm 545$ & $113 \pm 318$ & 1.6406 & n.s. \\
\hline Total & $8203 \pm 4641$ & $8016 \pm 4686$ & $5787 \pm 10051$ & 4.0498 & n.s. \\
\hline
\end{tabular}

Impact of forest proximity on food security, dietary diversity, and agricultural productivity

The proximity to Munesa Forest had no effect on household food security per se (Table 3, Fig. 2a), probably because of a lack of difference in the production of staples, but it had a significantly positive effect on dietary diversity (Table 3, Fig. 2b). Higher dietary diversity closer to the forest was explained by a higher prevalence of homegardens and higher livestock ownership (Table 4). More farms closer to the forest had homegardens because they tended to have larger livestock herds (Fig. 3), which produced more manure that was preferentially applied on homegardens, as revealed by group interviews and observations. The availability of manure for farms closer to the forest was also higher because they tended to use forest wood instead of livestock dung as fuel.

Thus, higher livestock ownership in farms closer to the forest compared with farms farther away was central in explaining the increase in dietary diversity with increasing proximity to the forest. Larger livestock herds of all species (except chicken) in farms that were closer to the forest compared with farms that were farther away was permitted by the use of a larger quantity of biomass from the forest (and other commons) as feed (Table 6). Larger livestock herds also contributed to the higher dietary diversity of households that were closer to the forest, directly through the production of milk and milk products and meat and animal products (as demonstrated by the much higher livestock productivity in the near zone compared with the two other zones) (Fig. 5b), and more indirectly through the production of manure, which facilitated the existence of homegardens - true hot spots of nutrient-dense food items. The proximity to the forest may also explain the higher number of beehives (Table 2) and the higher consumption of the food group sugar, sugar products, and honey (Fig. 2c) in the near and intermediate zones compared with the distant zone, due to the greater availability of pollen and nectar provided by trees.

Homegardens were key in explaining the higher consumption of almost all food groups, including roots and tubers (through enset and potato), pulses (through faba bean), meat and animal products (through eggs), fruits, milk and milk products (through fodder produced in homegardens; e.g., enset leaves) and sugar, sugar products, and honey (through honey). In addition, crop diversity in homegardens increased with increasing proximity to Munesa Forest (Table 2). This appears to be due to the higher prevalence of enset, which is known to modify local biophysical conditions in ways that may be favorable to other crops by capturing rainwater with its fan-shaped leaves and fibrous pseudostem and by modifying the microclimate under its canopy (i.e., they are described as "spacemakers") (Kanshie 2002). The presence of enset may be conditioned by the amount of manure applied (higher closer to the forest), as this crop is known to require high soil fertility (Kanshie 2002).

Although farmers in the distant zone were closer to the main market of Arsi Negele and had transformed their landscape for crop production more than had farmers in the two other zones, their crop productivity was not notably higher (Fig. 5a). This questions the validity of the paradigm of the modern conventional approach to agricultural intensification based on landscape simplification and high dependence on external inputs. Conversely, although farmers in the near zone applied equal rates of mineral fertilizers and more manure than did farmers in the two other zones, it had no influence on overall crop productivity (Fig. 5a). This is likely because manure was not spread evenly in the farmland but instead was concentrated in homegardens, which influenced the quality of crop production but not its quantity.

These findings support more integrated landscape approaches to agriculture and food production, which represent a paradigm shift from the modern conventional approach to agricultural productivity (Tscharntke et al. 2005, Sayer et al. 2013). Landscape approaches are based on the interconnections between land uses, including transfer of nutrients from natural and seminatural areas to farmland, as found in this study. Although not investigated here, natural and seminatural areas may also subsidize farmland with beneficial organisms that provide several regulating services, including pollination and pest control (Bianchi et al. 2006, Garibaldi et al. 2013). Through these multiple interactions, landscape approaches may be used to design farming systems that are more sustainable, self-organized (i.e., maintained through energy cycling instead of regular input of energy in the form of mechanical operations and agrochemicals), and often more productive (Tittonell 2014). As illustrated by the findings of this study, landscape approaches could also be one of the foundations of nutrition-sensitive agriculture.

\section{Forest sustaining agriculture: flows of biomass from forest to farms}

Munesa Forest subsidized farms in the near zone with an annual flow of biomass that is estimated to be greater than 6 tons per farm, which provided positive effects on the diversity of crop and livestock products in these farms. Livestock played a key role in the transfer of nutrients from Munesa Forest (and other commons) to farms by providing manure. In addition, fuelwood from Munesa Forest (and other commons) allowed for more manure to be available as organic amendment instead of being burned as fuel in the absence of wood energy (Table 5). 
The fact that farms from the near zone relied mostly on Munesa Forest for fuel and feed, and not from the zone itself, may explain greater tree cover in this zone compared with the other zones. Similarly, farms from the intermediate zone used a large communal grazing area - located outside the zone - for fuel and feed, which may explain the greater tree cover in this zone compared with the distant zone. Group and individual interviews revealed that most deforestation in the area occurred between 1974 and 1982, when the imperial regime was replaced by a Marxist-Leninist regime that gave "land to the tillers" in Ethiopia. The area was said to be largely forested before that. It appears that deforestation was less intense in the most remote part of the study area (away from the main market of Arsi Negele) where more common resources (e.g., Munesa Forest, large communal grazing areas) were found in the vicinity. The retention of more trees closer to Munesa Forest may also contribute to the productivity and sustainability of farming, through erosion control (Young 1989), nutrient cycling (Chikowo et al. 2003), and regulation of the local climate (Ong et al. 2000). Trees may also provide habitats for beneficiary species, such as natural enemies that prey on yield-reducing pests (Dix et al. 1995). Finally, some tree species may fix atmospheric nitrogen (Danso et al. 1992), or mobilize phosphorus through root exudation or mycorrhiza (Watt and Evans 1999, Smith and Read 2008).

Are the observed transfers of nutrients from Munesa Forest to neighboring farmlands sustainable, or is the forest being mined at an unsustainable rate, thus threatening current farming systems and local diets? Based on the estimated mean quantity of biomass used as fuel and feed by the different farm types in the near zone, the number of farms from each farm type, and the estimated area of forest accessible to farms from the near zone (102 ha), the quantity of biomass harvested from the forest was estimated to be 2.89 tons fuelwood $\mathrm{ha}^{-1}$ forest and 1.34 tons feed $\mathrm{ha}^{-1}$ forest. Based on the study of Tesfaye (2007), conducted in a dry tropical Afromontane forest near the study area, this could represent a sustainable harvest: he estimated the stem diameter increment to be 6.3-11.6 tha-1 (i.e., more than double the quantity of fuelwood harvested from Munesa Forest estimated in this study) and the herbaceous biomass to be 5.5-6.6 $\mathrm{tha}^{-1}$ (i.e., more than four times the quantity of biomass grazed from Munesa Forest estimated in this study). However, large sections of Munesa Forest showed signs of degradation (Fig. 4c). Thus, the sustainability of the current use of Munesa Forest should be rigorously assessed.

\section{Implications for the design of nutrition-sensitive farms and landscapes}

In common with the findings of Ickowitz et al. (2014), but contrary to the thesis of Sibhatu et al. (2015), dietary diversity decreased when market access increased in this study. In remote settings such as the study area, encouraging production diversity will remain a major strategy to increase dietary diversity (Remans et al. 2015).

This study demonstrates that-under certain circumstanceslandscape approaches that consider the transfer of nutrients from forests to farmlands may be used as a basis for the design of nutrition-sensitive agriculture. Forests and pastures tend to be areas of accretion of nutrients because they are dominated by perennial plants - trees and perennial grasses - which are characterized by long residence time and deep and dense root systems, and thus by the ability to capture and recycle more carbon and nutrients than can annual crops (Sanchez et al. 1997). In this study, as in many others conducted in other farming systems around the world (Powell et al. 2004), livestock played the role of vector of nutrients from forests and pastures to croplands where food crops were produced. Thus, although livestock is increasingly portrayed as a growing global environmental threat (see e.g., Steinfeld et al. 2006), it plays an important role in the sustainability of many food production systems, and it contributes to the nutrition of millions of rural people directly, for example, through milk and milk products that are rich in highquality proteins and micronutrients such as zinc (Young and Pellett 1994, Murphy and Allen 2003), and indirectly through the nutrients they vector to fields and gardens (as demonstrated in this study). However, the use of livestock dung as organic amendment may be prevented if it is used as fuel instead. This study, similar to other studies conducted in Ethiopia (e.g., Duguma et al. 2014, Baudron et al. 2015), demonstrates the link between fuelwood availability and the quantity of manure applied annually.

\section{CONCLUSIONS}

In this study, the forest did not serve as a direct source of food products for rural people (aside from the anecdotic wild fruits occasionally eaten by young herders). Nevertheless, the forest was crucial in ensuring a high dietary diversity of rural households living near it by contributing large quantities of feed and fuelwood, which sustained agriculture and in particular ensured regular flows of nutrients to homegardens that locally served as production hot spots of nutrient-dense food items. Forests may also sustain agriculture in other ways, including through pollination, pest control, water regulation, and climate regulation (Foli et al. 2014, Reed et al. 2017).

These interactions have been largely ignored by the land-sparing and land-sharing approaches, which - since the seminal paper of Green et al. (2005) — constitute the main conceptual framework used by policy-makers when looking at the relations between agriculture and nature (Bennett 2017). It may be that positive interactions between forest and agriculture are not taken into account by the framework (which focuses largely on trade-offs) because it has been developed (and is being used) chiefly by conservation ecologists but not by agronomists. The contribution of agronomists to the framework is urgently needed for synergies not to be missed in the design of landscape mosaics that contribute to both biodiversity conservation and human well-being (Reed et al. 2016). In particular, agronomists may contribute to a better selection of proxies of "agricultural yield" when plotting yielddensity functions classically used to identify - in a particular context - species that are better suited to land sparing or land sharing. To the best of our knowledge, all the studies using such yield-density functions (e.g., Green et al. 2005, Kleijn et al. 2009, Clough et al. 2011, Phalan et al. 2011, Gabriel et al. 2013) have used crop productivity as the proxy of farming intensity/human well-being and have found strong trade-offs between maintaining biodiversity and increasing agricultural production/human wellbeing. From the results of this study, very different results would probably be obtained if livestock productivity, fuel availability, or dietary diversity were used as proxies of farming intensity/human well-being instead of crop productivity (synergies instead of trade-offs). 
The case of rural households living at the periphery of Munesa Forest is probably not isolated, and forests no doubt contribute in a similar way to the diet of millions of rural households living at the periphery of forests in developing countries. For these forests, which are often managed as common pool resources, to continue to play their key role of supporting rural livelihoods in areas that are often sustaining rapid land use changes, policy and institutions will have to be crafted to ensure they are managed sustainably (e.g., through self-governance) (Ostrom et al. 1992) and do not fall victims to the "tragedy of the commons" (Hardin 1968).

We conclude that nutrition-sensitive agriculture in remote rural settings that are dominated by mixed crop-livestock systems may be achieved through a combination of landscape management (and in particular the retention of patches of forest and pastures), livestock management (to transfer nutrients from forest and pastures to farmlands), and household energy management (i.e., guaranteeing alternative fuel sources to livestock dung).

Responses to this article can be read online at: http://www.ecologyandsociety.org/issues/responses. $\mathrm{php} / 9267$

\section{Acknowledgments:}

This research was funded by the Department for International Development (DFID) and the United States Agency for International Development (USAID) through the project "The New Agrarian Change" coordinated by the Centre for International Forestry Research, and by WHEAT CRP (www.wheat.org). We thank Kedir Gemedo, Hamid Tura, and Genemo Teshite for assisting with the fieldwork. Our gratitude also goes to Liz Deakin and Mrigesh Kshatriya for their contributions to the development of methods, and to Habtemariam Kassa for his assistance in the selection of the study area.

\section{LITERATURE CITED}

Arnold, M., B. Powell, P. Shanley, and T. C. H. Sunderland. 2011. EDITORIAL: Forests, biodiversity and food security. International Forestry Review 13(3):259-264. http://dx.doi. org/10.1505/146554811798293962

Baudron, F., A. Mamo, D. Tirfessa, and M. Argaw. 2015. Impact of farmland exclosure on the productivity and sustainability of a mixed crop-livestock system in the central Rift Valley of Ethiopia. Agriculture, Ecosystems \& Environment 207:109-118. http://dx.doi.org/10.1016/j.agee.2015.04.003

Beck, T., and C. Nesmith. 2001. Building on poor people's capacities: the case of common property resources in India and West Africa. World Development 29(1):119-133. http://dx.doi. org/10.1016/s0305-750x(00)00089-9

Bennett, E. M. 2017. Changing the agriculture and environment conversation. Nature Ecology and Evolution 1(January):1-2. http://dx.doi.org/10.1038/s41559-016-0018

Bianchi, F. J. J. A., C. J. H. Booij, and T. Tscharntke. 2006. Sustainable pest regulation in agricultural landscapes: a review on landscape composition, biodiversity and natural pest control. Proceedings of the Royal Society B: Biological Sciences 273 (1595):1715-1727. http://dx.doi.org/10.1098/rspb.2006.3530

Bilinsky, P., and A. Swindale. 2007. Months of adequate household food provisioning (MAHFP) for measurement of household food access: indicator guide. Food and Nutrition Technical Assistance III Project, U.S. Agency for International Development (USAID) and FHI 360.

Chikowo, R., P. Mapfumo, P. Nyamugafata, G. Nyamadzawo, and K. E. Giller. 2003. Nitrate-N dynamics following improved fallows and maize root development in a Zimbabwean sandy clay loam. Agroforestry Systems 59(3):187-195. http://dx.doi. org/10.1023/b:agfo.0000005219.07409.a0

Clough, Y., J. Barkmann, J. Juhrbandt, M. Kessler, T. C. Wanger, A. Anshary, D. Buchori, D. Cicuzza, K. Darras, D. D. Putra, S. Erasmi, R. Pitopang, C. Schmidt, C. H. Schulze, D. Seidel, I. Steffan-Dewenter, K. Stenchly, S. Vidal, M. Weist, A. C. Wielgoss, and T. Tscharntke. 2011. Combining high biodiversity with high yields in tropical agroforests. Proceedings of the National Academy of Sciences of the United States of America 108 (20):8311-8316. http://dx.doi.org/10.1073/pnas.1016799108

Danso, S. K. A., G. D. Bowen, and N. Sanginga. 1992. Biological nitrogen fixation in trees in agro-ecosystems. Plant and Soil 141 (1-2):177-196. http://dx.doi.org/10.1007/BF00011316

Dix, M. E., M. O. Harrell, R. J. Wright, L. Hodges, J. R. Brandle, M. M. Schoenberger, N. J. Sunderman, R. L. Fitzmaurice, L. J. Young, and K. G. Hubbard. 1995. Influences of trees on abundance of natural enemies of insect pests: a review. Agroforestry Systems 29:303-311. http://dx.doi.org/10.1007/ $\underline{\mathrm{BF} 00704876}$

Dounias, E., and A. Froment. 2006. When forest-based huntergatherers become sedentary: consequences for diet and health. Unasylva 57(224):26-33.

Duguma, L. A., P. A. Minang, O. E. Freeman, and H. Hager. 2014. System wide impacts of fuel usage patterns in the Ethiopian highlands: potentials for breaking the negative reinforcing feedback cycles. Energy for Sustainable Development 20:77-85. http://dx.doi.org/10.1016/j.esd.2014.03.004

Duriaux, J.-Y., and F. Baudron. 2016. Understanding people and forest interrelations along an intensification gradient in ArsiNegele, Ethiopia. Pages 14-53 in E. L. Deakin, M. Kshatriya, and T. C. H. Sunderland, editors. Agrarian change in tropical landscapes. Center for International Forestry Research, Bogor, Indonesia.

Fa, J. E., D. Currie, and J. Meeuwig. 2003. Bushmeat and food security in the Congo Basin: linkages between wildlife and people's future. Environmental Conservation 30(1):71-78. http:// dx.doi.org/10.1017/s0376892903000067

Foli, S., J. Reed, J. Clendenning, G. Petrokofsky, C. Padoch, and T. C. H. Sunderland. 2014. To what extent does the presence of forests and trees contribute to food production in humid and dry forest landscapes?: a systematic review protocol. Environmental Evidence 3(1):15. http://dx.doi.org/10.1186/2047-2382-3-15

Foote, J. A., S. P. Murphy, L. R. Wilkens, P. P. Basiotis, and A. Carlson. 2004. Dietary variety increases the probability of 
nutrient adequacy among adults. Journal of Nutrition 134 (7):1779-1785.

Gabriel, D., S. M. Sait, W. E. Kunin, and T. G. Benton. 2013. Food production vs. biodiversity: comparing organic and conventional agriculture. Journal of Applied Ecology 50(2):355364. http://dx.doi.org/10.1111/1365-2664.12035

Garibaldi, L. A., I. Steffan-Dewenter, R. Winfree, M. A. Aizen, R. Bommarco, S. A. Cunningham, C. Kremen, L. G. Carvalheiro, L. D. Harder, O. Afik, I. Bartomeus, F. Benjamin, V. Boreux, D. Cariveau, N. P. Chacoff, J. H. Dudenhöffer, B. M. Freitas, J. Ghazoul, S. S. Greenleaf, J. Hipólito, A. Holzschuh, B. Howlett, R. Isaacs, S. K. Javorek, C. M. Kennedy, K. M. Krewenka, S. Krishnan, Y. Mandelik, M. M. Mayfield, I. Motzke, T. Munyuli, B. A. Nault, M. Otieno, J. Petersen, G. Pisanty, S. G. Potts, R. Rader, T. H. Ricketts, M. Rundlöf, C. L. Seymour, C. Schüepp, H. Szentgyörgyi, H. Taki, T. Tscharntke, C. H. Vergara, B. F. Viana, T. C. Wanger, C. Westphal, N. Williams, and A.-M. Klein. 2013. Wild pollinators enhance fruit set of crops regardless of honey bee abundance. Science 339(6127):1608-1611. http://dx. doi.org/10.1126/science. 1230200

Geifus, F. 2008. 80 tools for participatory development: appraisal, planning, follow-up and evaluation. Inter-American Institute for Cooperation on Agriculture (IICA), San Jose, Costa Rica.

Gibbs, H. K., A. S. Ruesch, F. Achard, M. K. Clayton, P. Holmgren, N. Ramankutty, and J. A. Foley. 2010. Tropical forests were the primary sources of new agricultural land in the 1980s and 1990s. Proceedings of the National Academy of Sciences of the United States of America 107(38):16732-16737. http://dx.doi. org/10.1073/pnas.0910275107

Giller, K. E., P. A. Tittonell, M. C. Rufino, M. T. van Wijk, S. Zingore, P. Mapfumo, S. Adjei-Nsiah, M. Herrero, R. Chikowo, M. Corbeels, E. C. Rowe, F. Baijukya, A. Mwijage, J. Smith, E. Yeboah, W. J. van der Burg, O. M. Sanogo, M. Misiko, N. De Ridder, S. Karanja, C. Kaizzi, J. K'ungu, M. Mwale, D. Nwaga, G. C. Pacini, and B. Vanlauwe. 2011. Communicating complexity: integrated assessment of trade-offs concerning soil fertility management within African farming systems to support innovation and development. Agricultural Systems 104(2):191203. http://dx.doi.org/10.1016/j.agsy.2010.07.002

Gómez, M. I., C. B. Barrett, T. Raney, P. Pinstrup-Andersen, J. Meerman, A. Croppenstedt, B. Carisma, and B. Thompson. 2013. Post-green revolution food systems and the triple burden of malnutrition. Food Policy 42:129-138. http://dx.doi.org/10.1016/ j.foodpol.2013.06.009

Green, R. E., S. J. Cornell, J. P. W. Scharlemann, and A. Balmford. 2005. Farming and the fate of wild nature. Science 307(5709):550555. http://dx.doi.org/10.1126/science.1106049

Gryseels, G. 1988. Role of livestock on mixed smallholder farms in the Ethiopian Highlands: a case study from the Baso and Worena Wereda near Debre Berhan. Wageningen University, Wageningen, The Netherlands.

Hardin, G. 1968. The tragedy of the commons. Science 162 (June):1243-1248.

Hladik, C. M., S. Bahuchet, and I. De Garine. 1990. Food and nutrition in the African rain forest. Unesca/MAB, Paris, France.
Houérou, H. N. Le, and C. H. Hoste. 1977. Rangeland production and annual rainfall relations in the Mediterranean Basin and in the African Sahelo-Sudanian Zone. Journal of Range Management 30(3):181-189. http://dx.doi.org/10.2307/3897463

Ickowitz, A., B. Powell, M. A. Salim, and T. C. H. Sunderland. 2014. Dietary quality and tree cover in Africa. Global Environmental Change 24(1):287-294. http://dx.doi.org/10.1016/ j.gloenvcha.2013.12.001

International Food Policy Research Institute (IFPRI). 2014. Global nutrition report 2014: actions and accountability to accelerate the world's progress on nutrition. Washington, D.C., USA

Jagger, P., and J. Pender. 2003. The role of trees for sustainable management of less-favored lands: the case of eucalyptus in Ethiopia. Forest Policy and Economics 5:83-95. http://dx.doi. org/10.1016/S1389-9341(01)00078-8

Johnson, K. B., A. Jacob, and M. E. Brown. 2013. Forest cover associated with improved child health and nutrition: evidence from the Malawi Demographic and Health Survey and satellite data. Global Health: Science and Practice 1(2):237-248. http://dx. doi.org/10.9745/ghsp-d-13-00055

Jones, A. D., A. Shrinivas, and R. Bezner-Kerr. 2014. Farm production diversity is associated with greater household dietary diversity in Malawi: findings from nationally representative data. Food Policy 46:1-12. http://dx.doi.org/10.1016/j.foodpol.2014.02.001

Kanshie, K. T. 2002. Five thousand years of sustainablity? A case study on Gedeo land use (Southern Ethiopia). Treemail Publishers, Heelsum, The Netherlands.

Kaschula, S. A., W. E. Twine, and M. C. Scholes. 2005. Coppice harvesting of fuelwood species on a South African common: utilizing scientific and indigenous knowledge in community based natural resource management. Human Ecology 33(3):387-418. http://dx.doi.org/10.1007/s10745-005-4144-7

Kennedy, G., A. Berardo, C. Papavero, P. Horjus, T. Ballard, M. Dop, J. Delbaere, and I. D. Brouwer. 2010. Proxy measures of household food consumption for food security assessment and surveillance: comparison of the household dietary diversity and food consumption scores. Public Health Nutrition 13(12):2010 2018. http://dx.doi.org/10.1017/s136898001000145x

Kleijn, D., F. Kohler, A. Báldi, P. Batáry, E. D. Concepción, Y. Clough, M. Díaz, D. Gabriel, A. Holzschuh, E. Knop, A. Kovács, E. J. P. Marshall, T. Tscharntke, and J. Verhulst. 2009. On the relationship between farmland biodiversity and land-use intensity in Europe. Proceedings of the Royal Society B: Biological Sciences 276(1658):903-909. http://dx.doi.org/10.1098/rspb.2008.1509

Murphy, S. P., and L. H. Allen. 2003. Nutritional importance of animal source foods. Journal of Nutrition 133(1):3932S-3935S.

Muthayya, S., J. H. Rah, J. D. Sugimoto, F. F. Roos, K. Kraemer, and R. E. Black. 2013. The global hidden hunger indices and maps: an advocacy tool for action. PLoS ONE 8(6):1-12. http:// dx.doi.org/10.1371/journal.pone.0067860

Nasi, R., A. Taber, and N. Van Vliet. 2011. Empty forests, empty stomachs? Bushmeat and livelihoods in the Congo and Amazon Basins. International Forestry Review 13(3):355-368. http://dx. doi.org/10.1505/146554811798293872 
Ong, C. K., C. R. Black, J. S. Wallace, A. A. H. Khan, J. E. Lott, N. A. Jackson, S. B. Howard, and D. M. Smith. 2000. Productivity, microclimate and water use in Grevillea robusta-based agroforestry systems on hillslopes in semi-arid Kenya. Agriculture, Ecosystems \& Environment 80(1-2):121-141. http:// dx.doi.org/10.1016/s0167-8809(00)00144-4

Ostrom, E., J. Walker, and R. Gardner. 1992. Covenants with and without a sword: self-governance is possible. American Political Science Review 86:404 417. http://dx.doi.org/10.2307/1964229

Pfund, J. L., J. D. Watts, M. Boissière, A. Boucard, R. M. Bullock, A. Ekadinata, S. Dewi, L. Feintrenie, P. Levang, S. Rantala, D. Sheil, T. C. H. Sunderland, and Z. L. Urech. 2011. Understanding and integrating local perceptions of trees and forests into incentives for sustainable landscape management. Environmental Management 48(2):334-349. http://dx.doi.org/10.1007/s00267-011-9689-1

Phalan, B., M. Onial, A. Balmford, and R. E. Green. 2011. Reconciling food production and biodiversity conservation: land sharing and land sparing compared. Science 333(6047):12891291. http://dx.doi.org/10.1126/science. 1208742

Pimentel, D., C. Wilson, C. McCullum, R. Huang, P. Dwen, J. Flack, Q. Tran, T. Saltman, and B. Cliff. 1997. Economic and environmental benefits of biodiversity. BioScience 47(11):747757. http://dx.doi.org/10.2307/1313097

Powell, B., J. Hall, and T. Johns. 2011. Forest cover, use and dietary intake in the East Usambara Mountains, Tanzania. International Forestry Review 13(3):305-317. http://dx.doi.org/10.1505/146554811798293944

Powell, J. M., R. A. Pearson, and P. H. Hiernaux. 2004. Croplivestock interactions in the West African drylands. Agronomy Journal 96(2):469-483. http://dx.doi.org/10.2134/agronj2004.0469

Reed, J., J. van Vianen, E. L. Deakin, J. Barlow, and T. Sunderland. 2016. Integrated landscape approaches to managing social and environmental issues in the tropics: learning from the past to guide the future. Global Change Biology 22:2540-2554. http://dx.doi. org/10.1111/gcb.13284

Reed, J., J. van Vianen, S. Foli, J. Clendenning, K. Yang, M. MacDonald, G. Petrokofsky, C. Padoch, and T. Sunderland. 2017. Trees for life: the ecosystem service contribution of trees to food production and livelihoods in the tropics. Forest Policy and Economics. http://dx.doi.org/10.1016/j.forpol.2017.01.012

Remans, R., F. A. J. DeClerck, G. Kennedy, and J. Fanzo. 2015. Expanding the view on the production and dietary diversity link: scale, function, and change over time. Proceedings of the National Academy of Sciences of the United States of America 112(45): E6082. http://dx.doi.org/10.1073/pnas.1518531112

Remans, R., J. Fanzo, C. A. Palm, and F. A. J. DeClerck. 2011. Ecological approaches to human nutrition. In F. A. De Clerck, C. Rumbaitis Del Rio, and J. C. Ingram, editors. Integrating ecology and poverty alleviation and international development efforts: a practical guide. Springer, New York, USA.

Sanchez, P. A., R. J. Buresh, and R. R. B. Leakey. 1997. Trees, soils, and food security. Philosophical Transactions of the Royal Society B: Biological Sciences 352:949-961. http://dx.doi. org/10.1098/rstb.1997.0074
Sayer, J., T. C. H. Sunderland, J. Ghazoul, J.-L. Pfund, D. Sheil, E. Meijaard, M. Venter, A. K. Boedhihartono, M. Day, C. Garcia, C. van Oosten, and L. E. Buck. 2013. Ten principles for a landscape approach to reconciling agriculture, conservation, and other competing land uses. Proceedings of the National Academy of Sciences of the United States of America 110(21):8349-8356. http://dx.doi.org/10.1073/pnas. 1210595110

Shackleton, C., and S. Shackleton. 2004. The importance of nontimber forest products in rural livelihood security and as safety nets: a review of evidence from South Africa. South African Journal of Science 100(11-12):658-664. http://dx.doi.org/10.1016/ j.forpol.2006.03.004

Shackleton, C. M., S. E. Shackleton, E. Buiten, and N. Bird. 2007. The importance of dry woodlands and forests in rural livelihoods and poverty alleviation in South Africa. Forest Policy and Economics 9(5):558-577.

Sibhatu, K. T., V. V Krishna, and M. Qaim. 2015. Production diversity and dietary diversity in smallholder farm households. Proceedings of the National Academy of Sciences of the United States of America 112(34):10657-10662. http://dx.doi.org/10.1073/ pnas. 1510982112

Smith, S. E., and D. J. Read. 2008. Mycorrhizal symbiosis. Academic Press.

Steinfeld, H., P. Gerber, T. Wassenaar, V. Castel, M. Rosales, and C. de Haan. 2006. Livestock's long shadow: environmental issues and options. Food and Agriculture Organization of the United Nations, Rome, Italy.

Steyn, N. P., J. H. Nel, G. Nantel, G. Kennedy, and D. Labadarios. 2006. Food variety and dietary diversity scores in children: Are they good indicators of dietary adequacy? Public Health Nutrition 9(5):644-650. http://dx.doi.org/10.1079/PHN2005912

Termote, C., P. Van Damme, and B. D. a Djailo. 2011. Eating from the wild: Turumbu, Mbole and Bali traditional knowledge on non-cultivated edible plants, District Tshopo, DRCongo. Genetic Resources and Crop Evolution 58(4):585-618. http://dx. doi.org/10.1007/s10722-010-9602-4

Tesfaye, G. 2007. Structure, biomass and net primary production in dry tropical afromontane forest in Ethiopia. Addis Ababa University, Addis Ababa, Ethiopia.

Tittonell, P. A. 2014. Ecological intensification of agriculture sustainable by nature. Current Opinion in Environmental Sustainability 8:53-61. http://dx.doi.org/10.1016/j.cosust.2014.08.006

Tscharntke, T., A.-M. Klein, A. Kruess, I. Steffan-Dewenter, and C. Thies. 2005. Landscape perspectives on agricultural intensification and biodiversity - ecosystem service management. Ecology Letters 8(8):857-874. http://dx.doi.org/10.1111/ j.1461-0248.2005.00782.x

Vinceti, B., P. Eyzaguirre, and T. Johns. 2008. The nutritional role of forest plant foods for rural communities. Pages 65-96 in C. J. P. Colfer, editor. Human health and forests: a global overview of issues, practice and policy. Earthscan, London, U.K.

Watt, M., and J. R. Evans. 1999. Proteoid roots. Physiology and development. Plant Physiology 121:317-323. http://dx.doi. org/10.1104/pp.121.2.317 
Williams, T. O. 1998. Multiple uses of common pool resources in semi-arid West Africa: a survey of existing practices and options for sustainable resource management. ODI Natural Resource Perspectives 38(38).

Young, A. 1989. Agroforestry for soil conservation. CAB International.

Young, V. R., and P. L. Pellett. 1994. Plant proteins in relation to human protein and amino acid nutrition. American Journal of Clinical Nutrition 59(5):1203S-1212S. 
APPENDIX 1. Summary of the results of Model 1 (see text) for explaining the variability in the frequency of consumption (number of days per week) of cereals, grains and grain products, roots and tubers, pulses, vegetables, meat and animal products, and fruits. Significant effects $(\mathrm{P}<0.05)$ are shown in bold.

\begin{tabular}{|c|c|c|c|c|c|c|c|c|c|c|c|c|}
\hline \multirow[t]{2}{*}{ Model variables } & \multicolumn{2}{|c|}{$\begin{array}{l}\text { Cereals, } \\
\text { grains and } \\
\text { grain } \\
\text { products }\end{array}$} & \multicolumn{2}{|c|}{$\begin{array}{l}\text { Roots and } \\
\text { tubers }\end{array}$} & \multicolumn{2}{|l|}{ Pulses } & \multicolumn{2}{|c|}{ Vegetables } & \multicolumn{2}{|c|}{$\begin{array}{l}\text { Meat and } \\
\text { animal } \\
\text { products }\end{array}$} & \multicolumn{2}{|l|}{ Fruits } \\
\hline & value & $\begin{array}{l}P \\
\text { value }\end{array}$ & $\begin{array}{l}\text { t } \\
\text { value }\end{array}$ & $\begin{array}{l}P \\
\text { value }\end{array}$ & t & $\begin{array}{l}P \\
\text { value }\end{array}$ & $\begin{array}{l}\text { t } \\
\text { value }\end{array}$ & $\begin{array}{l}P \\
\text { value }\end{array}$ & $\begin{array}{l}\text { t } \\
\text { value }\end{array}$ & $\begin{array}{l}P \\
\text { value }\end{array}$ & t value & P value \\
\hline Intercept & 0.637 & $\begin{array}{l}0.52- \\
40\end{array}$ & 1.862 & $\begin{array}{l}0.06- \\
26\end{array}$ & -0.642 & $\begin{array}{l}0.52- \\
09\end{array}$ & 1.007 & $\begin{array}{l}0.31- \\
38\end{array}$ & -0.166 & $\begin{array}{l}0.86- \\
82\end{array}$ & 2.626 & 0.0086 \\
\hline Zone & -0.769 & $\begin{array}{l}0.44- \\
18\end{array}$ & -2.308 & $\begin{array}{l}0.02- \\
10\end{array}$ & -1.397 & $\begin{array}{l}0.16- \\
25\end{array}$ & -1.812 & $\begin{array}{l}0.06- \\
99\end{array}$ & 1.940 & $\begin{array}{l}0.05- \\
24\end{array}$ & -2.664 & 0.0077 \\
\hline Elevation & -0.485 & $\begin{array}{l}0.62- \\
77\end{array}$ & -3.163 & $\begin{array}{l}0.00- \\
16\end{array}$ & -2.001 & $\begin{array}{l}0.04- \\
54\end{array}$ & -0.059 & $\begin{array}{l}0.95- \\
30\end{array}$ & 1.386 & $\begin{array}{l}0.16- \\
57\end{array}$ & -5.353 & $<0.0001$ \\
\hline $\begin{array}{l}\text { Distance to nearest forest } \\
\text { patch }>0.5 \text { ha }\end{array}$ & -0.890 & $\begin{array}{l}0.37- \\
36\end{array}$ & 1.204 & $\begin{array}{l}0.22- \\
84\end{array}$ & -0.197 & $\begin{array}{l}0.84- \\
40\end{array}$ & -1.847 & $\begin{array}{l}0.06- \\
47\end{array}$ & & & & \\
\hline $\begin{array}{l}\text { Distance to nearest forest } \\
\text { patch }>0.25 \text { ha }\end{array}$ & 0.773 & $\begin{array}{l}0.43- \\
94\end{array}$ & -0.470 & $\begin{array}{l}0.63- \\
81\end{array}$ & 1.464 & $\begin{array}{l}0.14- \\
32\end{array}$ & 1.592 & $\begin{array}{l}0.11- \\
15\end{array}$ & & & & \\
\hline $\begin{array}{l}\text { Distance to nearest grassland } \\
\text { patch }>0.5 \text { ha }\end{array}$ & -0.170 & $\begin{array}{l}0.86- \\
53\end{array}$ & 4.040 & $\begin{array}{l}0.00- \\
01\end{array}$ & 2.479 & $\begin{array}{l}0.01- \\
32\end{array}$ & 1.212 & $\begin{array}{l}0.22- \\
53\end{array}$ & & & -2.968 & 0.0030 \\
\hline $\begin{array}{l}\text { Distance to nearest grassland } \\
\text { patch }>0.25 \text { ha }\end{array}$ & -0.365 & $\begin{array}{l}0.71- \\
48\end{array}$ & -2.892 & $\begin{array}{l}0.00- \\
38\end{array}$ & 0.210 & $\begin{array}{l}0.83- \\
34\end{array}$ & -1.788 & $\begin{array}{l}0.07- \\
38\end{array}$ & -1.172 & $\begin{array}{l}0.24- \\
11\end{array}$ & 1.921 & 0.0548 \\
\hline Distance to nearest road & 0.168 & $\begin{array}{l}0.86- \\
64\end{array}$ & 0.175 & $\begin{array}{l}0.86- \\
12\end{array}$ & -2.397 & $\begin{array}{l}0.01- \\
65\end{array}$ & -0.341 & $\begin{array}{l}0.73- \\
31\end{array}$ & 0.420 & $\begin{array}{l}0.67- \\
48\end{array}$ & 0.027 & 0.9782 \\
\hline $\begin{array}{l}\text { Sex of the head of the } \\
\text { household }\end{array}$ & & & 1.735 & $\begin{array}{l}0.08- \\
28\end{array}$ & -0.835 & $\begin{array}{l}0.40- \\
39\end{array}$ & -0.706 & $\begin{array}{l}0.48- \\
00\end{array}$ & 0.767 & $\begin{array}{l}0.44- \\
32\end{array}$ & -0.496 & 0.6200 \\
\hline $\begin{array}{l}\text { Age of the head of the } \\
\text { household }\end{array}$ & 0.820 & $\begin{array}{l}0.41- \\
21\end{array}$ & 2.051 & $\begin{array}{l}0.04- \\
03\end{array}$ & 0.918 & $\begin{array}{l}0.35- \\
85\end{array}$ & 0.353 & $\begin{array}{l}0.72- \\
42\end{array}$ & -0.498 & $\begin{array}{l}0.61- \\
85\end{array}$ & -2.844 & 0.0044 \\
\hline Family size & -0.258 & $\begin{array}{l}0.79- \\
67\end{array}$ & 0.922 & $\begin{array}{l}0.35- \\
66\end{array}$ & 0.580 & $\begin{array}{l}0.56- \\
20\end{array}$ & 0.187 & $\begin{array}{l}0.85- \\
17\end{array}$ & 0.617 & $\begin{array}{l}0.53- \\
72\end{array}$ & 1.304 & 0.1921 \\
\hline $\begin{array}{l}\text { Head of the household } \\
\text { schooled }\end{array}$ & 0.284 & $\begin{array}{l}0.77- \\
66\end{array}$ & 1.757 & $\begin{array}{l}0.07- \\
90\end{array}$ & -2.521 & $\begin{array}{l}0.01- \\
17\end{array}$ & 1.222 & $\begin{array}{l}0.22- \\
19\end{array}$ & -1.692 & $\begin{array}{l}0.09- \\
06\end{array}$ & -1.825 & 0.0680 \\
\hline Tertiary education & & & 0.326 & $\begin{array}{l}0.74- \\
41\end{array}$ & 2.481 & $\begin{array}{l}0.01- \\
31\end{array}$ & 1.049 & $\begin{array}{l}0.29 \\
42\end{array}$ & 2.922 & $\begin{array}{l}0.00- \\
35\end{array}$ & 0.705 & 0.4811 \\
\hline Remittances & -0.143 & $\begin{array}{l}0.88- \\
66\end{array}$ & 0.700 & $\begin{array}{l}0.48- \\
36\end{array}$ & 1.936 & $\begin{array}{l}0.05- \\
28\end{array}$ & 1.141 & $\begin{array}{l}0.25- \\
38\end{array}$ & -0.516 & $\begin{array}{l}0.60- \\
57\end{array}$ & 0.692 & 0.4887 \\
\hline Paid work & -0.799 & $\begin{array}{l}0.42- \\
43\end{array}$ & 1.640 & $\begin{array}{l}0.10- \\
10\end{array}$ & & & 0.594 & $\begin{array}{l}0.55- \\
23\end{array}$ & -0.171 & $\begin{array}{l}0.86- \\
43\end{array}$ & 0.114 & 0.9090 \\
\hline Year land was cleared & -0.547 & $\begin{array}{l}0.58- \\
43\end{array}$ & 0.109 & $\begin{array}{l}0.91- \\
32\end{array}$ & 1.493 & $\begin{array}{l}0.13- \\
54\end{array}$ & -1.040 & $\begin{array}{l}0.29- \\
82\end{array}$ & 0.393 & $\begin{array}{l}0.69- \\
46\end{array}$ & 0.136 & 0.8919 \\
\hline Year farming started & 0.491 & $\begin{array}{l}0.62- \\
35\end{array}$ & -0.111 & $\begin{array}{l}0.91- \\
17\end{array}$ & 1.232 & $\begin{array}{l}0.21- \\
79\end{array}$ & -0.229 & $\begin{array}{l}0.81- \\
92\end{array}$ & -2.081 & $\begin{array}{l}0.03- \\
74\end{array}$ & 1.629 & 0.1034 \\
\hline Farm area & 1.633 & $\begin{array}{l}0.10- \\
24\end{array}$ & -1.481 & $\begin{array}{l}0.13- \\
85\end{array}$ & 0.928 & $\begin{array}{l}0.35- \\
33\end{array}$ & 2.029 & $\begin{array}{l}0.04- \\
24\end{array}$ & -2.056 & $\begin{array}{l}0.03- \\
98\end{array}$ & -4.059 & $<0.0001$ \\
\hline Zone $\times$ Elevation & & & 3.513 & $\begin{array}{l}0.00- \\
04\end{array}$ & 3.126 & $\begin{array}{l}0.00- \\
18\end{array}$ & 1.292 & $\begin{array}{l}0.19- \\
64\end{array}$ & -2.244 & $\begin{array}{l}0.02- \\
49\end{array}$ & 3.289 & 0.0010 \\
\hline $\begin{array}{l}\text { Zone } \times \text { Distance to nearest } \\
\text { forest patch }>0.5 \text { ha }\end{array}$ & 0.898 & $\begin{array}{l}0.36- \\
94\end{array}$ & -1.101 & $\begin{array}{l}0.27- \\
09\end{array}$ & 0.079 & $\begin{array}{l}0.93- \\
73\end{array}$ & 1.856 & $\begin{array}{l}0.06- \\
35\end{array}$ & & & & \\
\hline $\begin{array}{l}\text { Zone } \times \text { Distance to nearest } \\
\text { forest patch }>0.25 \text { ha }\end{array}$ & -0.816 & $\begin{array}{l}0.41- \\
47\end{array}$ & 0.723 & $\begin{array}{l}0.46- \\
96\end{array}$ & -1.455 & $\begin{array}{l}0.14- \\
58\end{array}$ & -1.575 & $\begin{array}{l}0.11- \\
53\end{array}$ & & & & \\
\hline $\begin{array}{l}\text { Zone } \times \text { Distance to nearest } \\
\text { grassland patch }>0.5 \text { ha }\end{array}$ & 0.256 & $\begin{array}{l}0.79- \\
76\end{array}$ & -4.283 & $\begin{array}{l}< \\
0.00- \\
01\end{array}$ & -1.008 & $\begin{array}{l}0.31- \\
33\end{array}$ & -0.986 & $\begin{array}{l}0.32- \\
39\end{array}$ & & & 3.577 & 0.0003 \\
\hline
\end{tabular}




\begin{tabular}{|c|c|c|c|c|c|c|c|c|c|c|c|c|}
\hline $\begin{array}{l}\text { Zone } \times \text { Distance to nearest } \\
\text { grassland patch }>0.25 \text { ha }\end{array}$ & 0.543 & $\begin{array}{l}0.58- \\
72\end{array}$ & 3.197 & $\begin{array}{l}0.00- \\
14\end{array}$ & -0.896 & $\begin{array}{l}0.37- \\
00\end{array}$ & 1.281 & $\begin{array}{l}0.20- \\
02\end{array}$ & 1.342 & $\begin{array}{l}0.17- \\
96\end{array}$ & -2.333 & 0.0196 \\
\hline Zone $\times$ Family size & 0.149 & $\begin{array}{l}0.88- \\
13\end{array}$ & -0.797 & $\begin{array}{l}0.42- \\
52\end{array}$ & -1.065 & $\begin{array}{l}0.28- \\
68\end{array}$ & -0.039 & $\begin{array}{l}0.96- \\
87\end{array}$ & -0.294 & $\begin{array}{l}0.76- \\
88\end{array}$ & -0.788 & 0.4307 \\
\hline $\begin{array}{l}\text { Zone } \times \text { Head of the } \\
\text { household schooled }\end{array}$ & -0.130 & $\begin{array}{l}0.89- \\
66\end{array}$ & -2.206 & $\begin{array}{l}0.02- \\
74\end{array}$ & 3.322 & $\begin{array}{l}0.00- \\
09\end{array}$ & -0.202 & $\begin{array}{l}0.83- \\
98\end{array}$ & 2.315 & $\begin{array}{l}0.02- \\
06\end{array}$ & 1.488 & 0.1367 \\
\hline Zone $\times$ Tertiary education & & & 0.889 & $\begin{array}{l}0.37- \\
39\end{array}$ & -2.690 & $\begin{array}{l}0.00- \\
71\end{array}$ & -1.139 & $\begin{array}{l}0.25- \\
45\end{array}$ & -1.870 & $\begin{array}{l}0.06- \\
15\end{array}$ & -0.084 & 0.9333 \\
\hline Zone $\times$ Remittances & 0.129 & $\begin{array}{l}0.89- \\
71\end{array}$ & -0.661 & $\begin{array}{l}0.50- \\
86\end{array}$ & -2.392 & $\begin{array}{l}0.01- \\
68\end{array}$ & -1.147 & $\begin{array}{l}0.25- \\
15\end{array}$ & 1.292 & $\begin{array}{l}0.19- \\
64\end{array}$ & -0.636 & 0.5250 \\
\hline Zone $\times$ Paid work & & & & & & & & & & & & \\
\hline Zone $\times$ Year land was cleared & 0.758 & $\begin{array}{l}0.44- \\
87\end{array}$ & -0.335 & $\begin{array}{l}0.73- \\
77\end{array}$ & -1.218 & $\begin{array}{l}0.22- \\
32\end{array}$ & 1.335 & $\begin{array}{l}0.18- \\
18\end{array}$ & -0.727 & $\begin{array}{l}0.46- \\
70\end{array}$ & 0.466 & 0.6412 \\
\hline Zone $\times$ Farm area & -1.666 & $\begin{array}{l}0.09- \\
56\end{array}$ & 1.515 & $\begin{array}{l}0.12- \\
98\end{array}$ & -0.975 & $\begin{array}{l}0.32- \\
94\end{array}$ & -2.104 & $\begin{array}{l}0.03- \\
54\end{array}$ & 2.084 & $\begin{array}{l}0.03- \\
72\end{array}$ & 3.978 & 0.0001 \\
\hline
\end{tabular}


APPENDIX 2. Summary of the results of Model 2 (see text) for explaining the variability in the frequency of consumption (number of days per week) of cereals, grains and grain products, roots and tubers, pulses, vegetables, meat and animal products, and fruits. Significant effects $(\mathrm{P}<0.05)$ are shown in bold (Homegarden: presence of absence of a homegarden, TLU: Tropical Livestock Unit).

\begin{tabular}{|c|c|c|c|c|c|c|c|c|c|c|c|c|}
\hline \multirow[t]{2}{*}{ Model variables } & \multicolumn{2}{|c|}{$\begin{array}{l}\text { Cereals, grains } \\
\text { and grain } \\
\text { products }\end{array}$} & \multicolumn{2}{|c|}{$\begin{array}{l}\text { Roots and } \\
\text { tubers }\end{array}$} & \multicolumn{2}{|l|}{ Pulses } & \multicolumn{2}{|c|}{ Vegetables } & \multicolumn{2}{|c|}{$\begin{array}{l}\text { Meat and } \\
\text { animal } \\
\text { products }\end{array}$} & \multicolumn{2}{|l|}{ Fruits } \\
\hline & $\begin{array}{l}\text { t } \\
\text { value }\end{array}$ & $\begin{array}{l}P \\
\text { value }\end{array}$ & $\begin{array}{l}\text { t } \\
\text { value }\end{array}$ & $\begin{array}{l}P \\
\text { value }\end{array}$ & $\begin{array}{l}\text { t } \\
\text { value }\end{array}$ & $\begin{array}{l}P \\
\text { value }\end{array}$ & $\begin{array}{l}\text { t } \\
\text { value }\end{array}$ & $\begin{array}{l}P \\
\text { value }\end{array}$ & t & $\begin{array}{l}P \\
\text { value }\end{array}$ & $\begin{array}{l}\text { t } \\
\text { value }\end{array}$ & P value \\
\hline Intercept & -0.554 & 0.5800 & -0.351 & 0.7254 & -2.134 & 0.0328 & -0.202 & 0.8400 & 0.676 & 0.4990 & -3.004 & 0.0027 \\
\hline Homegarden & 0.479 & 0.6320 & 6.357 & $\begin{array}{l}< \\
0.0001\end{array}$ & 2.175 & 0.0296 & & & 1.153 & 0.2488 & 3.679 & 0.0002 \\
\hline Cattle (TLU) & -0.762 & 0.4460 & 1.030 & 0.3032 & -2.005 & 0.0449 & -0.111 & 0.9115 & 0.127 & 0.8988 & & \\
\hline Sheep and goats (TLU) & 0.405 & 0.6850 & 3.166 & 0.0015 & 2.161 & 0.0307 & -0.331 & 0.7404 & 1.867 & 0.0619 & 4.686 & $<0.0001$ \\
\hline Equines (TLU) & 0.691 & 0.4900 & -2.155 & 0.0312 & 2.508 & 0.0122 & 1.856 & 0.0634 & -2.173 & 0.0298 & -0.473 & 0.6363 \\
\hline Beehives & & & 4.246 & $\begin{array}{l}< \\
0.0001\end{array}$ & 0.314 & 0.7532 & 0.485 & 0.6277 & 2.625 & 0.0087 & 1.411 & 0.1583 \\
\hline $\begin{array}{l}\text { Chicken } \\
\text { Sex of the head of the } \\
\text { household } \\
\text { Age of the head of the } \\
\text { household }\end{array}$ & 0.330 & 0.7410 & 1.170 & 0.2421 & 1.100 & 0.2713 & -0.700 & 0.4837 & -0.601 & 0.5479 & 0.706 & 0.4799 \\
\hline Family size & -0.505 & 0.6140 & 3.214 & 0.0013 & 0.695 & 0.4869 & & & 2.904 & 0.0037 & 3.164 & 0.0016 \\
\hline $\begin{array}{l}\text { Head of the household } \\
\text { schooled }\end{array}$ & & & -1.126 & 0.2600 & 1.782 & 0.0747 & 3.543 & 0.0004 & 1.772 & 0.0765 & 0.657 & 0.5109 \\
\hline Tertiary education & 0.676 & 0.4990 & 3.638 & 0.0003 & 0.286 & 0.7750 & -0.501 & 0.6166 & 3.082 & 0.0021 & 2.942 & 0.0033 \\
\hline Remittances & 0.339 & 0.7350 & 3.424 & 0.0006 & 0.628 & 0.5302 & -0.826 & 0.4087 & 2.690 & 0.0071 & 1.775 & 0.0758 \\
\hline Paid work & -1.023 & 0.3060 & 0.362 & 0.7172 & -0.515 & 0.6065 & 0.760 & 0.4470 & -0.638 & 0.5232 & -0.567 & 0.5704 \\
\hline Year land was cleared & 0.780 & 0.4350 & 0.165 & 0.8690 & 1.623 & 0.1046 & 0.458 & 0.6472 & 0.846 & 0.3975 & 1.924 & 0.0544 \\
\hline Year farming started & 0.441 & 0.6600 & 0.245 & 0.8061 & 1.387 & 0.1655 & 0.151 & 0.8801 & -1.791 & 0.0732 & 2.202 & 0.0277 \\
\hline $\begin{array}{l}\text { Homegarden } \times \text { Cattle } \\
(\text { TLU) }\end{array}$ & 0.784 & 0.4330 & -0.884 & 0.3767 & 1.000 & 0.3175 & -0.525 & 0.5994 & 0.187 & 0.8516 & & \\
\hline $\begin{array}{l}\text { Homegarden } \times \text { Sheep } \\
\text { and goats }(T L U)\end{array}$ & -0.162 & 0.8710 & -1.917 & 0.0552 & -1.480 & 0.1389 & -0.198 & 0.8428 & -1.264 & 0.2059 & -3.729 & 0.0002 \\
\hline $\begin{array}{l}\text { Homegarden } \times \text { Equines } \\
(\mathrm{TLU})\end{array}$ & -0.620 & 0.5350 & 1.945 & 0.0517 & -1.873 & 0.0610 & -2.004 & 0.0451 & 2.476 & 0.0133 & 0.688 & 0.4911 \\
\hline Homegarden $\times$ Beehives & & & -4.084 & $\begin{array}{l}< \\
0.0001\end{array}$ & -0.530 & 0.5963 & -0.723 & 0.4695 & -2.940 & 0.0033 & -1.422 & 0.1550 \\
\hline Homegarden $\times$ Chicken & -0.273 & 0.7850 & -2.403 & 0.0163 & -0.554 & 0.5795 & 1.223 & 0.2214 & 0.470 & 0.6380 & 0.937 & 0.3486 \\
\hline
\end{tabular}


APPENDIX 3. Summary of the results of Model 1 (see text) for explaining the variability in the frequency of consumption (number of days per week) of milk and milk products, fats and oil, spices and condiments, sugar, sugar products and honey, and snack and processed foods. Significant effects $(\mathrm{P}<0.05)$ are shown in bold.

\begin{tabular}{|c|c|c|c|c|c|c|c|c|c|c|}
\hline \multirow[t]{2}{*}{ Model variables } & \multicolumn{2}{|c|}{$\begin{array}{l}\text { Milk and milk } \\
\text { products }\end{array}$} & \multicolumn{2}{|c|}{ Fats and oil } & \multicolumn{2}{|c|}{$\begin{array}{l}\text { Spices and } \\
\text { condiments }\end{array}$} & \multicolumn{2}{|c|}{$\begin{array}{l}\text { Sugar, sugar } \\
\text { products and } \\
\text { honey }\end{array}$} & \multicolumn{2}{|c|}{$\begin{array}{l}\text { Snack and } \\
\text { processed foods }\end{array}$} \\
\hline & t value & $\begin{array}{l}P \\
\text { value }\end{array}$ & $t$ value & $\begin{array}{l}P \\
\text { value }\end{array}$ & t value & $\begin{array}{l}P \\
\text { value }\end{array}$ & $t$ value & $\begin{array}{l}P \\
\text { value }\end{array}$ & $t$ value & $P$ value \\
\hline Intercept & 0.241 & 0.8092 & 0.678 & 0.4980 & -0.917 & 0.3590 & 1.666 & $\begin{array}{l}0.09 \\
57\end{array}$ & 4.735 & $<0.0001$ \\
\hline Zone & & & -1.027 & 0.3040 & 0.855 & 0.3920 & -3.157 & $\begin{array}{l}0.00- \\
16\end{array}$ & -4.345 & $<0.0001$ \\
\hline Elevation & -1.321 & 0.1865 & -0.636 & 0.5250 & 0.730 & 0.4650 & -4.195 & $\begin{array}{l}< \\
0.00- \\
01\end{array}$ & -4.057 & $<0.0001$ \\
\hline $\begin{array}{l}\text { Distance to nearest forest patch }> \\
0.5 \text { ha }\end{array}$ & 0.675 & 0.4995 & -0.522 & 0.6020 & & & 4.056 & $\begin{array}{l}< \\
0.00- \\
01\end{array}$ & & \\
\hline $\begin{array}{l}\text { Distance to nearest forest patch > } \\
0.25 \text { ha }\end{array}$ & & & 0.449 & 0.6530 & 0.178 & 0.8590 & 0.377 & $\begin{array}{l}0.70- \\
58\end{array}$ & & \\
\hline $\begin{array}{l}\text { Distance to nearest grassland patch } \\
>0.5 \mathrm{ha}\end{array}$ & -0.899 & 0.3687 & -0.123 & 0.9020 & 0.238 & 0.8120 & -1.067 & $\begin{array}{l}0.28- \\
61\end{array}$ & -0.216 & 0.8293 \\
\hline $\begin{array}{l}\text { Distance to nearest grassland patch } \\
>0.25 \text { ha }\end{array}$ & 0.495 & 0.6209 & -0.475 & 0.6350 & -0.421 & 0.6730 & -0.777 & $\begin{array}{l}0.43- \\
71\end{array}$ & 1.573 & 0.1158 \\
\hline Distance to nearest road & 1.152 & 0.2494 & -0.321 & 0.7490 & -0.611 & 0.5410 & -1.482 & $\begin{array}{l}0.13- \\
83\end{array}$ & 0.079 & 0.9368 \\
\hline Sex of the head of the household & 0.380 & 0.7041 & -0.155 & 0.8770 & & & -0.590 & $\begin{array}{l}0.55- \\
49\end{array}$ & -0.566 & 0.5711 \\
\hline Age of the head of the household & 1.982 & 0.0475 & -0.284 & 0.7760 & & & 0.874 & $\begin{array}{l}0.38- \\
23\end{array}$ & -2.575 & 0.0100 \\
\hline Family size & 0.471 & 0.6376 & & & -0.335 & 0.7370 & 0.906 & $\begin{array}{l}0.36- \\
50\end{array}$ & 3.439 & 0.0006 \\
\hline Head of the household schooled & -0.875 & 0.3818 & -0.534 & 0.5930 & -0.225 & 0.8220 & 0.470 & $\begin{array}{l}0.63- \\
86\end{array}$ & -2.197 & 0.0280 \\
\hline Tertiary education & 2.924 & 0.0035 & 0.228 & 0.8190 & -0.153 & 0.8780 & 1.742 & $\begin{array}{l}0.08- \\
15\end{array}$ & 3.571 & 0.0004 \\
\hline Remittances & 0.741 & 0.4589 & -0.805 & 0.4210 & -1.175 & 0.2400 & 0.589 & $\begin{array}{l}0.55- \\
62\end{array}$ & & \\
\hline Paid work & -2.010 & 0.0445 & -0.104 & 0.9170 & & & 1.008 & $\begin{array}{l}0.31- \\
36\end{array}$ & -0.514 & 0.6074 \\
\hline Year land was cleared & 0.798 & 0.4252 & -0.622 & 0.5340 & & & 0.270 & $\begin{array}{l}0.78- \\
69\end{array}$ & -2.743 & 0.0061 \\
\hline Year farming started & 0.119 & 0.9049 & 0.766 & 0.4430 & 1.010 & 0.3120 & 0.803 & $\begin{array}{l}0.42- \\
18\end{array}$ & -1.354 & 0.1759 \\
\hline Farm area & -3.297 & 0.0010 & 1.149 & 0.2510 & 0.211 & 0.8330 & -4.866 & $\begin{array}{l}< \\
0.00- \\
01\end{array}$ & -1.348 & 0.1778 \\
\hline Zone $\times$ Elevation & 1.922 & 0.0546 & & & & & 5.082 & $\begin{array}{l}< \\
0.00- \\
01\end{array}$ & 4.362 & $<0.0001$ \\
\hline $\begin{array}{l}\text { Zone } \times \text { Distance to nearest forest } \\
\text { patch }>0.5 \text { ha }\end{array}$ & -1.186 & 0.2356 & 0.559 & 0.5760 & & & & & & \\
\hline $\begin{array}{l}\text { Zone } \times \text { Distance to nearest forest } \\
\text { patch }>0.25 \text { ha }\end{array}$ & 1.401 & 0.1612 & -0.449 & 0.6540 & -0.128 & 0.8980 & -0.252 & $\begin{array}{l}0.80- \\
10\end{array}$ & & \\
\hline
\end{tabular}




\begin{tabular}{|c|c|c|c|c|c|c|c|c|c|c|}
\hline $\begin{array}{l}\text { Zone } \times \text { Distance to nearest } \\
\text { grassland patch }>0.5 \mathrm{ha}\end{array}$ & 0.718 & 0.4728 & 0.178 & 0.8580 & -0.315 & 0.7530 & 2.197 & $\begin{array}{l}0.02- \\
80\end{array}$ & -0.015 & 0.9877 \\
\hline $\begin{array}{l}\text { Zone } \times \text { Distance to nearest } \\
\text { grassland patch }>0.25 \text { ha }\end{array}$ & 0.816 & 0.4147 & 0.413 & 0.6800 & 0.560 & 0.5750 & -0.618 & $\begin{array}{l}0.53- \\
64\end{array}$ & -1.949 & 0.0513 \\
\hline Zone $\times$ Family size & -0.359 & 0.7199 & 0.183 & 0.8550 & 0.186 & 0.8520 & -1.357 & $\begin{array}{l}0.17- \\
47\end{array}$ & -3.041 & 0.0024 \\
\hline $\begin{array}{l}\text { Zone } \times \text { Head of the household } \\
\text { schooled }\end{array}$ & 1.539 & 0.1237 & 0.463 & 0.6430 & 0.307 & 0.7590 & 0.117 & $\begin{array}{l}0.90- \\
68\end{array}$ & 1.759 & 0.0786 \\
\hline Zone $\times$ Tertiary education & -2.618 & 0.0089 & -0.614 & 0.5390 & 0.334 & 0.7380 & -0.745 & $\begin{array}{l}0.45- \\
63\end{array}$ & -3.220 & 0.0013 \\
\hline Zone $\times$ Remittances & -1.309 & 0.1906 & 0.583 & 0.5600 & 0.990 & 0.3220 & -0.881 & $\begin{array}{l}0.37- \\
83\end{array}$ & & \\
\hline \multicolumn{11}{|l|}{ Zone $\times$ Paid work } \\
\hline Zone $\times$ Year land was cleared & -2.056 & 0.0398 & 0.990 & 0.3220 & -0.860 & 0.3900 & -0.683 & $\begin{array}{l}0.49- \\
46\end{array}$ & & \\
\hline Zone $\times$ Farm area & 3.439 & 0.0006 & -1.175 & 0.2400 & -0.180 & 0.8570 & 4.910 & $\begin{array}{l}< \\
0.00- \\
01\end{array}$ & 1.387 & 0.1654 \\
\hline
\end{tabular}


APPENDIX 4. Summary of the results of Model 2 (see text) for explaining the variability in the frequency of consumption (number of days per week) of milk and milk products, fats and oil, spices and condiments, sugar, sugar products and honey, and snack and processed foods. Significant effects $(\mathrm{P}<0.05)$ are shown in bold (Homegarden: presence of absence of a homegarden, TLU: Tropical Livestock Unit).

\begin{tabular}{|c|c|c|c|c|c|c|c|c|c|c|}
\hline \multirow[t]{2}{*}{ Model variables } & \multicolumn{2}{|c|}{$\begin{array}{l}\text { Milk and milk } \\
\text { products }\end{array}$} & \multicolumn{2}{|c|}{ Fats and oil } & \multicolumn{2}{|c|}{$\begin{array}{l}\text { Spices and } \\
\text { condiments }\end{array}$} & \multicolumn{2}{|c|}{$\begin{array}{l}\text { Sugar, sugar } \\
\text { products and honey }\end{array}$} & \multicolumn{2}{|c|}{$\begin{array}{l}\text { Snack and process } \\
\text { foods }\end{array}$} \\
\hline & t value & $\begin{array}{l}P \\
\text { value }\end{array}$ & $t$ value & $P$ value & $t$ value & P value & t value & P value & t value & P value \\
\hline Intercept & -0.486 & 0.6272 & -0.775 & 0.4390 & 0.357 & 0.7210 & -0.059 & 0.9533 & 3.481 & 0.0005 \\
\hline Homegarden & 6.139 & $\begin{array}{l}< \\
0.0001\end{array}$ & 0.581 & 0.5610 & & & 3.153 & 0.0016 & 1.907 & 0.0565 \\
\hline Cattle (TLU) & 4.784 & $\begin{array}{l}< \\
0.0001\end{array}$ & -0.832 & 0.4050 & 0.486 & 0.6270 & 2.035 & 0.0418 & -1.744 & 0.0812 \\
\hline Sheep and goats (TLU) & 2.689 & 0.0072 & 0.427 & 0.6700 & 0.277 & 0.7820 & 2.477 & 0.0133 & & \\
\hline Equines (TLU) & -2.131 & 0.0331 & 0.626 & 0.5310 & 0.193 & 0.8470 & -2.040 & 0.0414 & 3.005 & 0.0027 \\
\hline Beehives & 3.800 & 0.0001 & 0.195 & 0.8450 & 0.264 & 0.7920 & 1.746 & 0.0808 & & \\
\hline Chicken & 0.281 & 0.7787 & 0.909 & 0.3630 & -0.597 & 0.5510 & 1.130 & 0.2587 & -2.172 & 0.0299 \\
\hline $\begin{array}{l}\text { Sex of the head of the } \\
\text { household } \\
\text { Age of the head of the } \\
\text { household }\end{array}$ & & & & & & & & & & \\
\hline Family size & 1.650 & 0.0990 & -0.497 & 0.6190 & -0.410 & 0.6820 & 1.340 & 0.1801 & -1.852 & 0.0641 \\
\hline $\begin{array}{l}\& ; \text { Head of the household } \\
\text { schooled }\end{array}$ & -0.295 & 0.7679 & & & 0.521 & 0.6020 & 0.478 & 0.6323 & 1.387 & 0.1656 \\
\hline Tertiary education & 2.038 & 0.0416 & -0.722 & 0.4700 & 0.591 & 0.5550 & 2.547 & 0.0109 & 3.267 & 0.0011 \\
\hline Remittances & 0.674 & 0.5004 & -0.351 & 0.7260 & -1.056 & 0.2910 & 1.331 & 0.1831 & 2.217 & 0.0266 \\
\hline Paid work & -3.431 & 0.0006 & -0.425 & 0.6710 & 0.454 & 0.6500 & 0.424 & 0.6716 & -1.938 & 0.0527 \\
\hline Year land was cleared & 0.456 & 0.6481 & 0.855 & 0.3930 & -0.724 & 0.4690 & -0.653 & 0.5140 & -2.573 & 0.0101 \\
\hline Year farming started & & & 0.629 & 0.5290 & 0.653 & 0.5140 & 0.833 & 0.4046 & -1.987 & 0.0469 \\
\hline $\begin{array}{l}\text { Homegarden } \times \text { Cattle } \\
(\text { TLU) }\end{array}$ & -3.086 & 0.0020 & 1.172 & 0.2410 & -0.309 & 0.7580 & -1.557 & 0.1195 & 1.639 & 0.1012 \\
\hline $\begin{array}{l}\text { Homegarden } \times \text { Sheep and } \\
\text { goats }(\text { TLU) }\end{array}$ & -2.112 & 0.0347 & -0.455 & 0.6490 & & & -2.179 & 0.0293 & & \\
\hline $\begin{array}{l}\text { Homegarden } \times \text { Equines } \\
(\mathrm{TLU})\end{array}$ & 2.048 & 0.0406 & -0.384 & 0.7010 & -0.142 & 0.8870 & 1.693 & 0.0905 & -2.460 & 0.0139 \\
\hline Homegarden $\times$ Beehives & -3.612 & 0.0003 & -0.194 & 0.8460 & -0.235 & 0.8140 & -1.713 & 0.0868 & & \\
\hline Homegarden $\times$ Chicken & 0.595 & 0.5518 & -1.033 & 0.3020 & 0.288 & 0.7730 & 0.230 & 0.8179 & & \\
\hline
\end{tabular}


APPENDIX 5. Summary of the results of Model 1 (see text) for explaining the variability presence/absence of a homegarden and crop diversity in homegarden. Significant effects $(\mathrm{P}<0.05)$ are shown in bold.

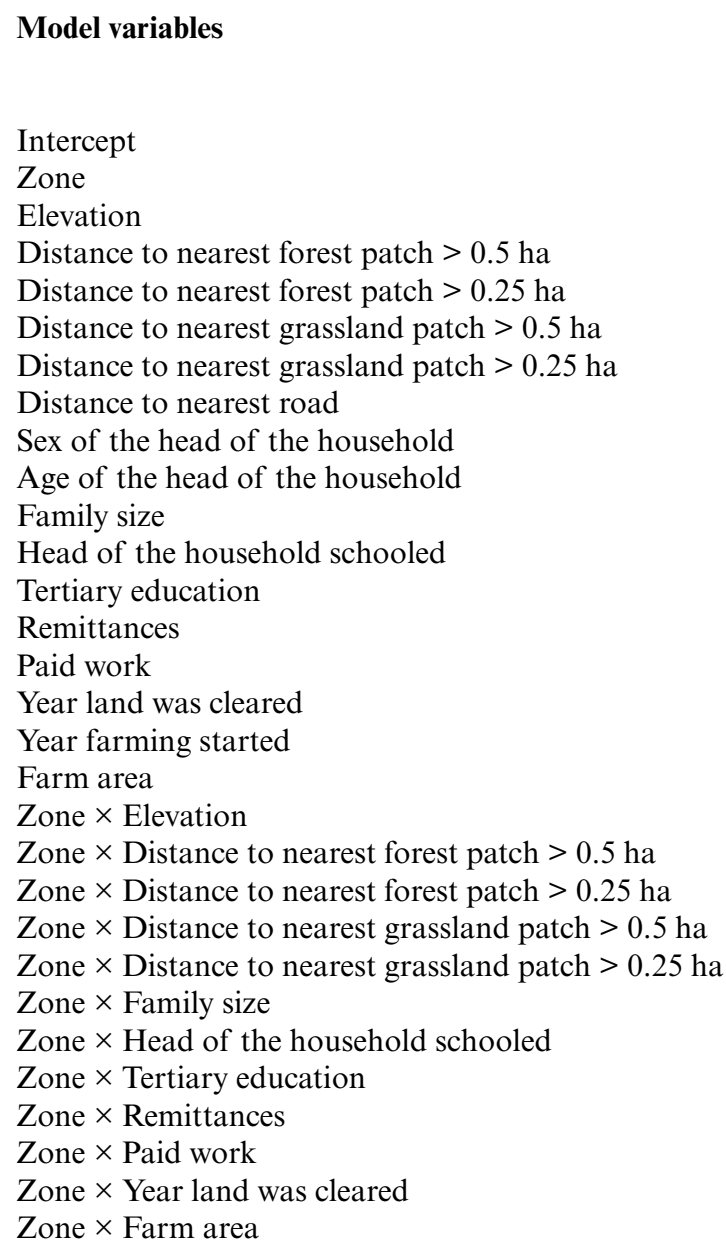

\begin{tabular}{|c|c|c|c|}
\hline \multicolumn{2}{|c|}{$\begin{array}{l}\text { Presence/Absence of a } \\
\text { homegarden }\end{array}$} & \multicolumn{2}{|c|}{ Crop diversity in homegar } \\
\hline t value & $P$ value & t value & P value \\
\hline 0.263 & 0.7923 & 1.745 & 0.0833 \\
\hline-1.338 & 0.1810 & & \\
\hline \multirow[t]{2}{*}{1.135} & 0.2565 & 0.404 & 0.6871 \\
\hline & & 0.631 & 0.5290 \\
\hline-0.481 & 0.6305 & -0.972 & 0.3330 \\
\hline-1.375 & 0.1692 & 1.964 & 0.0516 \\
\hline 1.069 & 0.2849 & & \\
\hline 0.155 & 0.8768 & 0.947 & 0.3455 \\
\hline-0.327 & 0.7438 & -0.167 & 0.8676 \\
\hline-0.278 & 0.7811 & 0.980 & 0.3289 \\
\hline 2.494 & 0.0126 & 0.114 & 0.9091 \\
\hline-1.467 & 0.1425 & -0.556 & 0.5789 \\
\hline 0.318 & 0.7502 & 1.374 & 0.1718 \\
\hline-0.343 & 0.7317 & 1.090 & 0.2776 \\
\hline 0.254 & 0.7994 & 0.660 & 0.5103 \\
\hline-1.324 & 0.1855 & -1.684 & 0.0946 \\
\hline 1.494 & 0.1351 & -0.296 & 0.7680 \\
\hline 2.134 & 0.0328 & 2.565 & 0.0114 \\
\hline \multirow[t]{2}{*}{0.770} & 0.4411 & -1.736 & 0.0849 \\
\hline & & -0.691 & 0.4906 \\
\hline 0.298 & 0.7654 & & \\
\hline-0.446 & 0.6558 & 3.320 & 0.0012 \\
\hline-2.083 & 0.0372 & -0.128 & 0.8981 \\
\hline 1.717 & 0.0860 & 0.494 & 0.6223 \\
\hline-0.350 & 0.7265 & -1.502 & 0.1355 \\
\hline 0.241 & 0.8093 & -0.866 & 0.3881 \\
\hline 1.104 & 0.2695 & 1.773 & 0.0786 \\
\hline-1.549 & 0.1213 & -2.607 & 0.0102 \\
\hline
\end{tabular}


APPENDIX 6. Summary of the results of Model 2 (see text) for explaining the variability presence/absence of a homegarden and crop diversity in homegarden. Significant effects $(\mathrm{P}<0.05)$ are shown in bold (Enset: presence of absence of enset in the homegarden, TLU: Tropical Livestock Unit).

\section{Model variables}

Intercept

Enset

Cattle (TLU)

Sheep and goats (TLU)

Equines (TLU)

Beehives

Chicken

Sex of the head of the household

Age of the head of the household

Family size

Head of the household schooled

Tertiary education

Remittances

Paid work

Year land was cleared

Year farming started

Enset $\times$ Cattle (TLU)

Enset $\times$ Sheep and goats (TLU)

Enset $\times$ Equines (TLU)

Enset $\times$ Beehives

Enset $\times$ Chicken
Presence/Absence of a

homegarden

$t$ value

$-1.821$

2.448

0.789

4.898

0.707

0.098

0.154

2.058

0.9217

0.8773

0.0396

\section{Crop diversity in homegarden}

$\begin{array}{ll}\text { t value } & P \text { value } \\ 0.541 & 0.5897 \\ -4.949 & <0.0001 \\ -0.795 & 0.4280 \\ -0.667 & 0.5061 \\ -1.636 & 0.1042 \\ -1.751 & 0.0821 \\ 0.434 & 0.6650\end{array}$

$-1.010$

$-1.187$

0.836

1.082

0.306

0.216

$-0.493$

1.212

0.657

1.329

$-0.431$
0.3142

0.2371

0.4044

0.2810

0.7603

0.8290

0.6231

0.2274

0.5123

0.1861
0.6674 